\title{
Disciplining entrenched managers through corporate governance reform: Implications for risk-taking behavior
}

\section{Oksana Pryshchepa}

Accounting and Finance Section, Cardiff University Business School, Cardiff, UK

\section{Correspondence}

Oksana Pryshchepa, Accounting and Finance Section, Cardiff University Business School, Cardiff CF10 3EU, UK.

Email: PryshchepaO@cardiff.ac.uk

\begin{abstract}
Research question/issue This paper examines how enhanced monitoring by corporate boards following the passage of the Sarbanes-Oxley Act of 2002 and concurrent reforms to stock exchange rules (SOX) mitigated risk-related agency conflicts prevalent in entrenched firms.

Research findings/insights Post-SOX, entrenched firms increased risky and valueenhancing investments. These investments were financed by reductions in financial slack and dividend payouts and by lower cost of debt. The specific mechanism driving the positive changes in corporate policies of entrenched firms is the SOX requirement of an independent compensation committee. Managers of entrenched firms previously noncompliant with this requirement are rewarded with more equity-based pay after SOX, which strengthened their incentives to pursue value-creating riskier investments. Only firms with low information asymmetry benefit from this requirement.

Theoretical/academic implications The paper provides evidence of a disciplining effect of the critically important governance legislation on firms with entrenched management. The findings suggest that, by imposing an additional layer of discipline on managers, SOX increased managers' willingness to take on riskier but more valueenhancing projects that were previously stifled in entrenched firms. The paper underscores the roles of an independent compensation committee and information cost in alleviating managerial risk avoidance.

Practitioner/policy implications The paper has implications for the ongoing debate among policymakers and legislators on the costs and benefits of SOX and for future governance reforms. Legal enforcement of stricter board requirements can realign investment policies with shareholders' interests even in the presence of valuereducing firm-specific arrangements that entrench managers. However, majority independent board and fully independent audit and compensation committees do not rein in chief executive officer (CEO)'s risk aversion. It is a fully independent compensation committee that is instrumental in incentivizing CEOs to pursue risky projects that also add value. Firms and policymakers need to be aware that the effectiveness
\end{abstract}


of the independent compensation committee in designing optimal pay policies depends on the access to timely and accurate information. Other mechanisms need to be considered to enhance risk-taking in entrenched firms operating in high cost information environments.

\section{KEYWORDS}

Corporate governance, antitakeover provisions, managerial entrenchment, risk-taking, Sarbanes-Oxley Act

"Taking less risk than is optimal is not safer; it just locks in a worse outcome."

(Brown, 2011, p. 35).

\section{INTRODUCTION}

Risk-taking is fundamental to producing economic growth and welfare (e.g., John et al., 2008). Yet, managerial risk aversion and career concerns create incentives for managers to invest in projects with less risk and possibly negative net present values (Amihud \& Lev, 1981; Coles et al., 2006). This risk-related agency conflict between managers and shareholders becomes especially acute as shareholder governance weakens and managerial ability to pursue self-interest (i.e., entrenchment) increases (Gormley \& Matsa, 2016). Whether corporate governance regulations that increase board independence and realign managerial incentives can be effective in alleviating this conflict is therefore an important and so far little explored question. Specifically, can regulatory-imposed improvements in board composition and practices discipline entrenched managers by forcing them to refocus on riskier and more valueenhancing projects? This paper addresses this question.

According to the managerial entrenchment hypothesis, a higher number of antitakeover provisions (ATPs) subject managers to less monitoring and disciplinary power of the market for corporate control, leading to managerial entrenchment (e.g., Sundaramurthy, 2000). Because managers hold undiversified portfolios and hence are exposed to significant human capital risk, they have a preference to reduce it by engaging in projects with less risk than optimal from the viewpoint of shareholder value maximization or even in projects that lower shareholders' wealth while also reducing risk (e.g., Holmström, 1999). Gormley and Matsa (2016) refer to this managerial misbehavior as "playing it safe" and demonstrate that it indeed manifests in firms with poor external shareholder governance as measured by the number of ATPs adopted by the firm. ${ }^{1}$

One of the mechanisms to alleviate this risk-related conflict is by empowering the board to establish appropriate incentives and to discipline management. While prior literature shows that boards are instrumental in moderating managerial preference for private benefits and avoiding costly effort (e.g., Scholten, 2005; Hazarika et al., 2012), there is no evidence on the role of internal corporate governance in incentivizing managers to increase investments in risky projects to the benefit of shareholders. I present such evidence in this paper.
Using the passage of the Sarbanes-Oxley Act and concurrent reforms to national stock exchange rules (hereinafter collectively referred to as "SOX") ${ }^{2}$ as a positive shock to a firm's internal governance, I test the hypothesis that risk-taking and investment of highly entrenched firms significantly increased, leading to enhancements in firm value and operating performance. I focus on SOX as an exogenous governance shock because it mandated more independent boards and board committees and tightened regulatory requirements on firm's disclosures and internal controls. Specifically, SOX wrote into law the requirement of independence of the majority of board directors and of all members of nominating, compensation, and audit committees. This mandatory increase in board and committees' independence significantly reduced managerial discretion and power over previously insider-dominated boards (e.g., Linck et al., 2009). Hence, SOX can be expected to moderate managerial preferences for risk reduction and increase value-creating risk-taking and investment even when external shareholder governance, proxied by ATPs, remained weak.

To measure risk-taking, I construct a total risk proxy similar to Armstrong and Vashishtha (2012) and Aretz et al. (2019) and decompose it into systematic and idiosyncratic components. Since it is more difficult for managers to diversify away or hedge firm-specific risk (Brisley et al., 2021), I expect that SOX had a greater impact on the idiosyncratic, rather than systematic, risk of firms with entrenched managers, if the reform was truly effective in moderating the riskrelated agency conflict.

As the main entrenchment proxy, I use E-index by Bebchuk et al. (2009) based on six ATPs written in firms' statutes and by-laws. Using this proxy mitigates the concern that a firm's managerial entrenchment is endogenous. E-index is a sticky measure of entrenchment that shows little within-firm variation over the sample period. ${ }^{3}$ In firms with higher values of E-index, managers are better insulated from internal pressure by shareholders and external control market and hence are in a better position to act upon their innate preference "to play it safe." Prior evidence supports this conjecture by documenting lower risk-taking in firms with higher E-index (Gormley \& Matsa, 2016). In this paper, however, I hypothesize that this negative impact of ATPs, that is of external governance arrangements, will weaken or even disappear following the improvements in internal governance due to SOX. Based on this hypothesis, I expect the interaction term between the entrenchment proxy and SOX dummy to be significantly positive in risk-taking and investment regressions. 
I find that entrenched firms indeed significantly increase risk following SOX. This finding withstands various robustness checks and is economically significant. Prior to SOX, firms with entrenchment level at the 75th percentile of the E-index distribution have total risk lower by $0.76 \%$ relative to firms at the 25 th percentile of the E-index distribution. ${ }^{4}$ However, after the passage of SOX, an increase in the entrenchment level from the 25th to the 75th percentile of the Eindex distribution leads to an increase in total risk by $1.7 \%$. Remarkably, decomposition of total risk into systematic and idiosyncratic components shows that both risk components significantly increase; however, an increase in idiosyncratic risk is almost double that in systematic risk. Specifically, post-SOX firms at the 75th percentile of Eindex distribution increase their systematic and idiosyncratic risk by, respectively, $0.8 \%$ and $1.5 \%$, relative to comparable firms at the 25 th percentile of the E-index distribution. This result suggests that SOX helped overcome overall managerial risk aversion, and importantly, the aversion to firm-specific risk, the exposure to which is of a particular concern to managers.

Further, following SOX, entrenched firms significantly increase their capital expenditures and growth in property, plant, and equipment. On the other hand, I do not find significant changes in expenditures on research and development (R\&D), which may be due to high opacity and specificity of these investments that cause information asymmetry problems and make them difficult for outsider-dominated boards to evaluate and monitor (Guldiken \& Darendeli, 2016). I also find no evidence of a significant increase in acquisition expense following SOX. This finding may suggest that, rather than increasing the amount spent on acquisitions, governance improvements due to SOX incentivized entrenched managers to channel more funds on acquisitions of more risky assets. This behavior cannot be picked up by looking at the changes in the levels of acquisitions; however, it can be captured by my risk proxies and is confirmed by the results of the risk-taking regressions.

$>$ An important question is whether SOX-induced increase in risktaking and related changes in investment policies in entrenched firms was value-enhancing. To answer this question, I study several measures of firm value and profitability and find significant improvements in most of them. For example, prior to SOX firms at the 75th percentile of the E-index distribution had industry-adjusted Tobin's Q lower by 0.13 and return on assets lower by $0.8 \%$, relative to similar firms at the 25 th percentile of the E-index distribution. Following SOX, firm value and performance improve in firms with higher entrenchment, resulting in no significant differences in the overall post-SOX levels of Tobin's $Q$ and ROA for firms with different entrenchment levels. Additionally, I show that after the passage of SOX, entrenched firms reduce financial slack and dividends and lower the effective cost of debt, hence, freeing up resources to finance the less conservative investment policy.

Crucially, I uncover a specific SOX provision and an economic mechanism that engendered these positive policy changes in entrenched firms. Fully independent compensation committees mandated by SOX readjusted pay packages of entrenched managers towards more equity-based compensation and thus strengthened the alignment of shareholder-manager interests. Moreover, I show that an independent compensation committee promotes optimal pay practices only in entrenched firms operating in low information cost environment. These findings suggest that outside directors serving on the compensation committee need to have access to timely and accurate information to design pay packages that provide high-powered incentives to take value-creating risks. Therefore, I conclude that SOX reform inadvertently was successful in abating managerial riskavoidance in entrenched firms.

This paper makes two contributions to the literature. The major contribution is to the corporate governance literature by providing empirical evidence on the positive impact of a specific corporate governance reform on risk-related agency problems. Cornelli et al. (2013) show that corporate governance reforms that increase board power and ability to act on the collected "soft information" are effective in strengthening active monitoring of managers and increase the likelihood of firing chief executive officer (CEO) for poor performance rather than for bad luck, hence inducing improvements in firm performance. Banerjee et al. (2015) examine the effect of SOX on decision-making of overconfident CEOs and find lower investment and risk-taking, higher dividend payout, and improvements in firm performance and value after SOX. These papers, however, do not examine how improved board composition affects preferences and actions of entrenched managers and thus whether it helps mitigate riskrelated agency conflicts. Notably, my paper differs from Banerjee et al. (2015) in an important way. I focus on the managerial riskavoidance problem and the ensuing suboptimal investment due to weak external governance, namely, the presence of ATPs. In contrast, Banerjee et al. (2015) study overinvestment and excessive risk-taking caused by a specific personal characteristic - managerial overconfidence. Entrenchment due to weak takeover market and overconfidence due to misguided personal beliefs result in different behavioral biases and opposite predictions about investment distortions (Gormley \& Matsa, 2016; Malmendier \& Tate, 2005). ${ }^{5}$

Another contribution is to the literature on the conditional effect of external corporate governance, proxied by takeover threats, on firm policies. Atanassov (2013) shows that the passage of antitakeover laws leads to declines in innovation and value in firms with lower leverage and smaller institutional holdings and firms in less competitive industries. Similarly, Giroud and Mueller (2010) find that the effect of external governance is more important in noncompetitive industries because managerial slack is higher in these industries. John et al. (2016) show that the presence of takeover threats matters more for firms with high excess cash holdings as managers of these firms are more likely to waste corporate resources. In this strand of literature, the paper closest to mine is by Gormley and Matsa (2016) who show that managers act on their inherent incentives to "play it safe" after the introduction of antitakeover laws that entrench managers. In contrast, my paper shows that a legislative enhancement of internal governance can mitigate risk-related agency conflicts even when firm- and state-level managerial entrenchment characteristics remain unchanged.

My findings have several implications for corporate governance policy and management practices. Firstly, I juxtapose the roles of the outsider-dominated board and oversight committees in mitigating the 
managerial risk-aversion problem. While having majority independent board and fully independent audit and nominating committees does not appear to rein in CEO's risk aversion, a fully independent compensation committee can provide an effective mechanism for incentivizing CEOs to pursue riskier investments that also add value. Hence, regulators should focus on compelling directors to design appropriate pay packages for CEOs.

Secondly, I demonstrate that the outcomes of governance regulations differ across firms, thereby confirming the limited usefulness of a "one-size-fits-all" policies. A positive impact of the compensation committee's full independence is evident only in firms with entrenched management that operate in low cost information environments. In contrast, a fully independent but misinformed compensation committee with sparse knowledge of firm's inside issues may be unsuccessful in designing pay packages that mitigate managerial riskaversion. Thus, other mechanisms need to be considered to enhance risk-taking in entrenched firms operating in a high cost information environment.

\section{2 | TESTABLE HYPOTHESES AND EMPIRICAL STRATEGY}

\section{1 | Managerial entrenchment and "playing it safe" incentives}

According to the managerial entrenchment hypothesis, ATPs weaken shareholder governance and increase managerial power and entrenchment. Legal barriers to takeovers make it easier for incumbent managers to act on their self-interest and undertake suboptimal strategies that shelter them from undesired negative outcomes that are typically increasing in firm risk (e.g., Jensen, 1988; Jensen \& Ruback, 1983). Gormley and Matsa (2016) provide empirical evidence of the existence and significance of such "playing it safe" managerial behavior following the introduction of state antitakeover laws. Specifically, they show that, after the adoption of ATPs, managers reduce stock volatility and distress risk by undertaking diversifying acquisitions that at the same time destroy shareholders' value.

\subsection{New corporate governance regulations}

In contrast to antitakeover laws, which weaken external corporate governance, a series of major reforms adopted in 2002-2003 in the United States dramatically improved internal corporate governance. The impetus for these reforms were numerous high-profile corporate accounting scandals in the United States during 2000-2001, which incited calls for enhancements of financial reporting, legal accountability, board structure, and oversight in public firms. The Sarbanes-Oxley Act passed by the U.S. congress in July 2002 was a key legislation in these reforms. ${ }^{6}$ Among its many provisions, it raised the requirements for financial disclosure and internal controls, increased corporate responsibility, and required a fully independent audit committee.
At the same time, the main stock exchanges, NYSE and NASDAQ, introduced revisions to its listing rules, which were approved by the Securities and Exchange Commission (SEC) in November 2003. These revisions included requirements of independence of the majority of directors and of the members of key committees (audit, compensation, and nominating) as well as of outside auditors. ${ }^{7}$ Moreover, the listing rules elaborated on the definition of an independent director and required the board to have additional meetings without company executives. They also required all members of an audit committee to be financially literate and at least one member of this committee to have accounting or financial management experience. Similarly to other corporate finance studies of these reforms, I refer to them collectively as SOX (Banerjee et al., 2015; Duchin et al., 2010).

\section{3 | Hypotheses}

Some of the key outcomes of SOX reforms were tightening of shareholders' control, empowering boards to be better monitors, and deterring managerial opportunism (Clark, 2005; Chhaochharia \& Grinstein, 2007). At the same time, SOX legislation improved transparency and quality of financial reporting and corporate disclosure, thus facilitating information acquisition by independent directors (Dey, 2010). As improved information environment helps directors to evaluate projects at a lower cost and more effectively (Adams \& Ferreira, 2007; Harris \& Raviv, 2008), it becomes easier for directors to identify and reject negative NPV projects and therefore to perform their monitoring role. To this end, prior studies document dramatic increases in board and committee independence, heightened activity of board committees, and the shift in board composition towards more qualified directors with specialized expertise, such as financial or legal (e.g., Linck et al., 2009; Duchin et al., 2010). An overall consensus in the literature on SOX is that its provisions created a positive shock to board monitoring and managerial incentives and established more vigilant governance and disclosure controls (e.g., Ashbaugh-Skaife et al., 2009; Arping \& Sautner, 2013).

The increase in the monitoring by the board and committees can curb managerial risk-reduction behavior by preventing collusions between the board and management, realigning managerial incentives, and facilitating firing CEO for poor performance (Cornelli et al., 2013; Guo \& Masulis, 2015). As the opportunities to act on the riskreduction incentives are more likely to arise in firms protected by ATPs, I expect that these firms benefit more from the disciplining effect of SOX on risk-taking policies and respond by increasing firm risk. The above discussion leads me to the first hypothesis.

Hypothesis 1.1. Following the passage of SOX, total risk and its systematic and idiosyncratic components increase in firms with higher levels of managerial entrenchment, relative to those with low levels.

Prior studies find that compensation-based incentives to increase risk induce CEOs to pursue projects with higher systematic risk but not idiosyncratic risk (Armstrong \& Vashishtha, 2012). This result manifests because a CEO can more effectively hedge the systematic risk of the firm by, for example, investing in the market indices 
(Jin, 2002; Garvey \& Milbourn, 2003). On the other hand, actively hedging exposure to firm-specific risk is more difficult due to contractual or regulatory restrictions that CEOs encounter for this type of hedging (Acharya \& Bisin, 2009). However, overcoming managerial aversion to idiosyncratic risk is important since it is this type of risk that drives the project's positive net present value (Pástor \& Veronesi, 2009). Hence, to conclude that SOX was successful in moderating managerial risk-reduction preferences, we should observe higher idiosyncratic risk-seeking by managers following the regulatory change. This prediction also relies on the prior evidence that stronger corporate governance, proxied, for example, by institutional ownership, is positively associated with idiosyncratic risk $(X u \&$ Malkiel, 2003). Hence, the next hypothesis is as follows:

Hypothesis 1.2. Following the passage of SOX, an increase in idiosyncratic risk for firms with entrenched managers is greater, relative to an increase in systematic risk.

Further, entrenched firms can "play it safe" by adopting a conservative investment policy, that is, by decreasing the overall level of corporate investment spending to negotiate for more attractive financing terms, such as bond covenants and interest rates (Garvey \& Hanka, 1999; John et al., 2008). Therefore, I expect that, all else being equal, a positive shock to shareholder governance induces entrenched firms to increase their corporate spending, such as capital expenditures and acquisitions, and growth of PP\&E and assets.

Hypothesis 2. Following the passage of SOX, entrenched firms increase their corporate investment.

Another type of investment that could be affected by the passage of SOX is R\&D spending. Prediction on the effect of SOX on R\&D is less clear-cut as arguments can be made both for an increase or decrease in this type of investment following an enhancement in governance. Some prior studies find that firms with weaker shareholder governance (entrenched management) tend to overinvest in long-term projects with higher fraction of human-specific capital, leading them to spend more on R\&D (Giroud \& Mueller, 2010). In this case, a positive effect of an increased shareholder control following SOX could be restraining this tendency of entrenched managers to overinvest in $R \& D$, producing a negative relation between $R \& D$ and entrenchment. On the other hand, several studies document that entrenched managers invest less in R\&D as these expenses represent intangible, longterm, and thus more risky investments that risk-averse managers tend to shy away from (Bhagat \& Welch, 1995; Kothari et al., 2002). In this case, the positive governance shock could force entrenched managers to increase investments in R\&D. Therefore, I formulate two alternative hypotheses to test the impact of SOX on R\&D spending.

Hypothesis 3A. Following SOX, entrenched firms increase their investment in $R \& D$.

Hypothesis 3B. Following SOX, entrenched firms decrease their investment in $R \& D$.

The important question in the analysis of the effects of SOX on entrenched firms is whether the changes in firms' risk-taking and investment strategies were beneficial for shareholders. Prior studies report lower firm value and worse operating performance in firms with higher levels of managerial entrenchment (e.g., Bebchuk et al., 2009; Bebchuk et al., 2013; Chang \& Zhang 2015). This result holds across different sample periods and suggests that managers who are less monitored and pressured by shareholders may engage in value-destroying activities. If SOX was effective in disciplining entrenched CEOs and in reducing investment distortions, we should observe improvements in firm value and performance following SOX. Therefore, the next hypothesis is as follows:

Hypothesis 4. Following the passage of SOX, firm value and operating performance increase in managerial entrenchment.

\subsection{Empirical strategy}

To test the central predictions of the paper (Hypotheses 1-4), I use a difference-in-differences (DiD) continuous design (Atanasov \& Black, 2016). I presume that, although almost all firms in the United States were subject to the shock, firms with higher managerial entrenchment (i.e., poor shareholder governance) would have a higher marginal benefit from the reform and hence are expected to be more sensitive to it. ${ }^{8}$ In this respect, the level of managerial entrenchment acts as a quasi-treatment, with highly entrenched firms receiving a higher dosage of treatment and representing a quasi-treated group, and low entrenched firms receiving smaller dosage of treatment and representing a quasi-control group.

To this end, I use the following DiD-like specification to evaluate the impact of SOX on firms with expected different sensitivity to the reform, where managerial entrenchment is the measure of this sensitivity:

$$
\begin{aligned}
\text { Risk }_{i, t} \text { Investment }_{i, t} & =\beta_{0}+\beta_{1} \text { Entrenchment }_{i, t-1} \\
& +\beta_{2} \text { SOX } \times \text { Entrenchment }_{i, t-1} \\
& +\theta X_{i, t-1}+\gamma_{j}+\gamma_{t}+\varepsilon_{i, t},
\end{aligned}
$$

where Risk and Investment are the risk-taking and investment proxies, respectively; SOX is a dummy variable that equals 1 for years 20022011 (post-SOX) $^{9}$; Entrenchment is the management entrenchment proxy; $X$ represents the set of firm control variables; $\gamma_{j}$ and $\gamma_{t}$ are industry and year fixed effects, respectively; $i$ and $t$ are firm and year subscripts, respectively. The specification does not include the indicator for the post-reform period, SOX, because it is subsumed by the year fixed effects. To take into account a multi-industry structure of sample firms, I define industry as the business segment (4-digit SIC code) with the largest sales in a given year. In all estimations, I use standard errors that allow for heteroscedasticity and clustering at the firm level. I also perform robustness checks controlling for time-invariant firm characteristics by replacing industry with firm fixed effects. ${ }^{10}$

The main interest is in $\beta_{2}$ coefficient on the interaction of the post-reform dummy (SOX) with sensitivity-to-shock (Entrenchment). It measures a DiD effect, that is, the change in the risk-taking and investment in entrenched firms relative to non-entrenched firms. Hypotheses 1.1, 2, and 3A predict that following SOX firms with higher entrenchment levels experience greater increases in risk and investment spending $\left(\beta_{2}^{\text {risk }}>0, \beta_{2}^{\text {inv }}>0, \beta_{2}^{R \& D}>0\right)$. An alternative 
Hypothesis $3 B$ for $R \& D$ predicts that $\beta_{2}^{R \& D}<0$. I also formally test Hypothesis 1.2 that an increase in idiosyncratic risk in firms with entrenched managers post-SOX is greater than that for systematic risk (i.e., $\beta_{2}^{\text {idios. risk }}>\beta_{2}^{\text {sys. risk }}$ )

To test Hypothesis 4, I replace the dependent variable in the DiD-continuous specification (1) with several value and performance measures, namely, Tobin's Q, market-to-book value of equity, return on assets (ROA), operating return, and cash flow. I also examine the change due to SOX in entrenched firms' financial health, proxied by Altman's (1968) Z score. Hypothesis 4 predicts a positive coefficient on the DiD-continuous term, SOX $\times$ Entrenchment ( $\beta_{2}^{\text {value }}>0$ ).

\section{3 | DATA SOURCES, SAMPLE CONSTRUCTION, AND VARIABLE DEFINITIONS}

To compute the risk proxies, I collect firm-level information on operating segments from Compustat Business Segment dataset. I use RiskMetrics to collect shareholder rights variables and construct the entrenchment proxy. Accounting data are from COMPUSTAT, and market data are from CRSP. Financial firms and utilities (SIC codes 6000-6999 and 4000-4999) are excluded. I also drop the issuers of dual class shares as they are characterized by poor governance (La Porta et al., 1999). The final sample contains 10,114 firm-year observations and 1,532 unique firms during the sample period from 1992 to $2011 .^{11}$ All control variables are lagged by one year.

\section{1 | Risk-taking and investment proxies}

Prior studies examining the effect of SOX on risk-taking focused on the volatility of equity returns as the main risk-taking proxy (e.g., Bargeron et al., 2010; Cohen et al., 2013; Albuquerque \& Zhu, 2018). A concern with this measure is that it reflects not only managerial risk-taking choices but more so the overall market and firm-specific environments, for example, firm's practices and disclosures (Bushee \& Noe, 2000), which were directly affected by the introduction of SOX. To address this concern, I construct an imputed investment-risk proxy similar to Aretz et al. (2019) and Armstrong and Vashishtha (2012), defined as the standard deviation of the portfolio of industries in which the firm operates. The advantage of this proxy is that industry weights are presumably determined directly by managerial decisions, while industry risk is less influenced by firm-specific informational environment and is therefore more stable over time. Hence, this imputed risk proxy better captures managerial decisions to alter firm's risk profile through changing the composition of industries in which the firm operates. At the same time, it mitigates the endogeneity issues associated with more common risk proxies, such as stock return volatility.

I consider a firm as a portfolio of business segments, which a manager can change to attain the desired combination of systematic and idiosyncratic risk. Specifically, the manager can introduce new segments, disinvest the existing ones, or change the weighting of the segments in the current business portfolio. I begin by constructing value-weighted pure-play industry portfolios that mimic the returns of the sample firms' segments. I use 4-digit SIC codes to define industries and require at least three single-segment firms to construct industry portfolios. Using the entire Compustat Business Segment Dataset over the sample period, I am able to construct 375 pure-play industry portfolios fulfilling this requirement. I then use the segment book values of assets at the end of the fiscal year to proxy the weight of an industry in the firm's total business portfolio and compute the imputed weekly return for firm $i$ in week $t$ as the weighted average of its industry segment returns:

$$
r_{i, t}=\sum_{S=1}^{S} \frac{A_{i}^{S}}{A_{i}} r_{t}^{S}
$$

where $r_{t}^{S}$ is the mimicking return of pure-play industry portfolio $s$ in week $t$ and $A_{i}^{S}$ and $A_{i}$ are, respectively, the book value of segment s of firm $i$ and the book value of firm's $i$ total assets. I define the measure of total risk, Total Risk, as annualized volatility of weekly imputed returns, $r_{i, t}$, over the previous 52 weeks.

To compute systematic and idiosyncratic risk proxies, I first run the Fama and French (1993) three-factor regression model using weekly returns computed as in Equation (2):

$$
r_{i, t}=\beta_{0, i}+\beta_{1, i} r_{M K T R F, t}+\beta_{2, i} r_{S M B, t}+\beta_{3, i} r_{H M L, t}+\epsilon_{i, t},
$$

where $r_{M K T R F, t}$ is the excess market return, $r_{S M B, t}$ is the size factor, $r_{H M L, t}$ is the value factor collected from Kenneth French's website, and $\epsilon_{i, t}$ is the error term.

I estimate Equation (3) for each firm at the end of each year and decompose it into systematic risk and idiosyncratic risk, defined as the square root of explained and unexplained variances, respectively. ${ }^{12}$ As my risk proxies are computed using industry returns over one (current) year only, unlike Armstrong and Vashishtha's (2012), they do not suffer from high skewness known to affect risk and return measures computed over long periods. ${ }^{13}$ However, I check that the main results remain the same if I use the natural logarithms of the risk measures (untabulated but available on request). Reporting nonlogarithmic measures in the tables eases the interpretation of the coefficients.

To examine the impact of SOX on investment strategies of entrenched firms, I use CAPEX (capital expenditures), R\&D (R\&D expenditures), Acquisition Expense (acquisition expense), and Net Investment (capital expenditures net of asset sales), all divided by fixed assets (PP\&E) in the previous year. Additionally, I examine PP\&E Growth and Asset Growth, defined, respectively, as growth in property, plant, and equipment and growth in total assets over the current year. Table A1 contains definitions of the main variables in the dataset and specifies data sources.

\section{2 | Entrenchment proxy}

To measure a firm's degree of managerial entrenchment, I construct the entrenchment index (E-index) as in Bebchuk et al. (2009). E-index 
is based on six ATPs collected by RiskMetrics for institutional investors and corporate governance researchers and gives a score, from 0 to 6 , for each ATP that the company has in a given year. ${ }^{14}$ Specifically, it includes four provisions that limit shareholders' voting power and thus enhance the discretionary power of managers (staggered boards, limits to shareholder by-law amendments, supermajority requirements for mergers, and supermajority requirements for charter amendments) and two ATPs that make it economically and time costly to remove managers (poison pills and golden parachutes) ${ }^{15}$ By construction, the E-index captures the balance of power between managers and shareholders, with higher index values (more ATPs) indicating weaker shareholder rights and greater managerial control over the company, hence entrenchment.

I use a firm's actual E-index values to examine the policy changes post-SOX for different managerial entrenchment levels. Additionally, I use a dummy variable Entrenched set to one if a firm's E-index is greater than 3 and set to zero if E-index is below 2. Splitting firms in this way corresponds to approximately top and bottom quartiles of the E-index distribution.

\subsection{Value and performance proxies}

I use several measures of firm value and operating performance. Firm value is proxied by Tobin's $Q$ defined as the market value of assets divided by the book value of assets. Shareholders' value is proxied by the marketto-book ratio, Market-to-Book Equity, computed as equity market value per share to book value per share. I use both raw and industry-adjusted Tobin's Q and Market-to-Book Equity computed by subtracting the mean value of all firms operating in the same industry based on the Fama and French (1997) 30 industry classifications. Performance is proxied by firm return on assets, ROA (ebit/at), Operating Return (ebitda/at), and Cash Flow $((\mathrm{dp}+\mathrm{ib}) / \mathrm{at})$. Firm financial health is proxied by Altman's $Z$ score. Table A1 provides further details on variable definitions.

\section{4 | Firm-level controls}

In regressions, I control for firm characteristics and policies that are known to affect risk-taking. I include firm size (LN(Assets)) since previous studies report a strong negative relation between firm size and risk (e.g., Coles et al. 2006; Low, 2009). The ratio of market-to-book value of equity (Market-to-Book Equity) controls for growth opportunities. I control for leverage measured as total debt divided by the total book value of assets (Leverage). Both positive and negative relations between leverage and risk are possible. A positive relation can be expected since firms with higher leverage levels have incentives to increase firm risk to transfer wealth from shareholders to debtholders (Jensen \& Meckling, 1976). At the same time, some studies show that more risky firms take on less leverage to avoid an increase in distress risk (Bradley et al., 1984). I therefore do not form any prediction on leverage. Further, I control for firm age defined as the natural logarithm of the number of years that the firm is listed in COMPUSTAT prior to fiscal year end (LN(FirmAge)). Firm age proxies for borrower's reputation as I expect older firms, that is, those with better reputation, to have lower risk (Diamond, 1989). To ensure that the results are not affected by outliers, I winsorize all variables at both the top and bottom one percentiles, except for leverage and firm age, winsorized only at the top one percentile.

\section{4 | EMPIRICAL RESULTS}

\section{1 | Descriptive statistics}

E-index is charter based and hence relatively time-invariant (Dikolli et al., 2014). Nonetheless, I check its stability in Table 1 by reporting sample composition and descriptive statistics by year for E-index and its annual change, $\Delta \mathrm{E}$-index. Indeed, managerial entrenchment remained largely stable over the sample period, with the overall mean and median of 2.29 and 2, respectively. The median and interquartile annual change in E-index are 0 for the entire period as well as separately for the pre-SOX and the post-SOX periods. This rigidity in $\mathrm{E}$ index over time validates its use as an exogenous proxy for managerial entrenchment. ${ }^{16}$ Although I later check the robustness of the results to holding E-index fixed at its pre-reform values, I use a time-varying $\mathrm{E}$-index in my main tests given the long 20 -year period I examine. ${ }^{17}$

\section{2 | Did SOX discipline entrenched CEOs?}

\subsection{1 | Univariate results}

Table 2 reports the mean values of the main outcome variables separately for firms with high and low levels of managerial entrenchment and the tests of differences in means by pre- and post-SOX periods. High (low) managerial entrenchment is defined as E-index greater than 3 (below 2). Columns (1)-(3) present statistics for the pre-SOX period (1992-2001) and show that during this period risk-taking, investment and firm value and performance were significantly lower in highly entrenched firms. For example, highly entrenched firms had total risk, capital expenditures, and Tobin's Q lower by $4.4 \%, 5.2 \%$, and 0.192 , respectively, compared to low entrenched firms.

In contrast, columns (4)-(6) show that following SOX, the risk levels of highly entrenched firms no longer differ significantly from those of firms with low entrenchment. The differences in capital expenditures and $R \& D$ remain, although they become noticeably smaller: Following SOX, highly entrenched firms make $1.5 \%$ less capital investments and have $5.7 \%$ lower R\&D relative to low entrenched firms. Acquisition investments, PP\&E growth, and assets growth become indistinguishable across the two groups of firms. Importantly, the difference in firm value (Tobin's Q) drops by almost three times, while firm's financial health ( $Z$ score) significantly improves for the highly entrenched group.

The last column subtracts the differences in outcome variables across highly and low entrenched firms for the post-SOX period from 
TABLE 1 Managerial entrenchment proxy by year

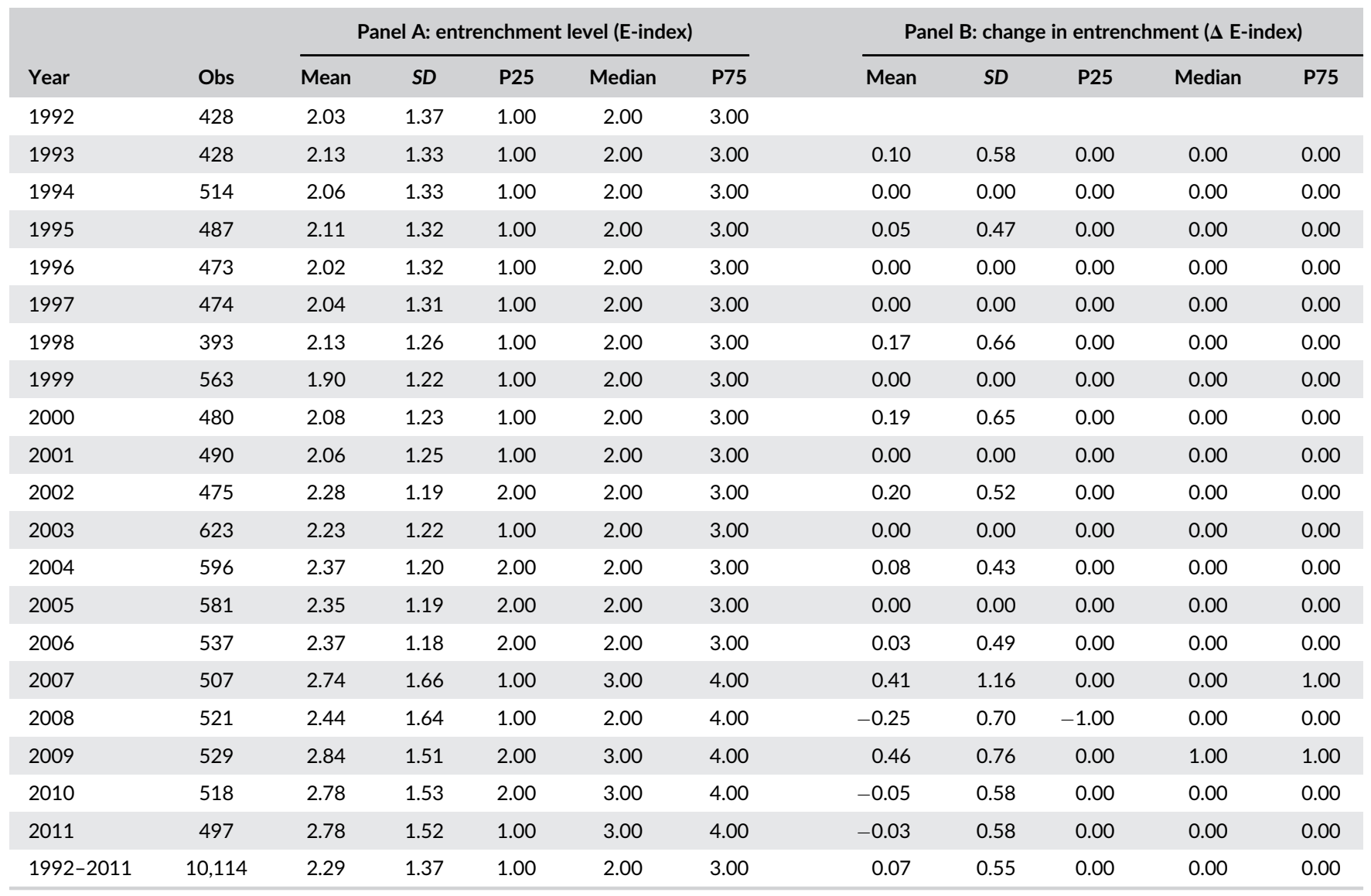

Note: The table shows summary statistics on managerial entrenchment ( $\mathrm{E}$-index) and change in entrenchment by year $\left(\Delta \mathrm{E}\right.$-index $=\mathrm{E}$-index $\mathrm{t}_{t}-\mathrm{E}$-index $\left.\mathrm{x}_{t-1}\right)$. Variable definitions are in Table A1. The sample period is 1992-2011.

the respective differences in the pre-SOX period and reports the tests of the differences. The univariate DiD estimates are highly significant $4.5 \%, 4.0 \%$, and $1.9 \%$ for total, idiosyncratic risk, and systematic risk, respectively. The smaller DiD value for the change in systematic risk suggests that the increase in the overall risk is primarily driven by the idiosyncratic component. The DiD values for investment variables are also all positive; however, they are significant only for capital expenditures (3.7\%), net investment (3.6\%), growth in PP\&E (4.8\%), and growth in assets (5.1\%). Firm value and financial health DiD estimates are positive 0.22 and 0.36 , respectively $(p<.001)$.

Overall, these univariate results are broadly consistent with the hypotheses of increased risk-taking and less conservative investment policy in entrenched firms following the adoption of SOX. However, the analysis in Table 2 fails to control for systematic differences across firms, and therefore, I turn to regression analysis next.

\subsection{2 | Multivariate results}

Table 3 reports the main results of the paper. Columns (1)-(3) that use E-index as an entrenchment proxy show that it attracts a negative and significant coefficient in all risk regressions, suggesting that prior to the SOX reform, managerial risk-taking was significantly lower in more entrenched firms. ${ }^{18}$ Specifically, for firms with entrenchment index at the 75th percentile of the distribution (E-index of 3 ), total risk was on average lower by $1.14 \%$ per year $(-0.381 \times 3 ; p<.05)$, relative to firms with zero entrenchment level. Respective values for systematic and idiosyncratic risks are $0.44 \%$ and $1.02 \%$ ( $p<.05$ for both), respectively. Consistent with Gormley and Matsa (2016), this result suggests that prior to the SOX reform, firms with more ATPs engaged in riskreducing strategies.

Notably, this behavior reverses following SOX. In column (1), the coefficient estimate on the DiD-continuous term is $0.846(p<.000)$ indicating that the total risk of firms with E-index at the 75th percentile of the distribution increased by $2.55 \%(0.846 \times 3)$ following the SOX reform relative to their counterparts with zero entrenchment level. ${ }^{19}$ Importantly, the increase is greater for the idiosyncratic component, relative to that for the systematic one. For each additional value of entrenchment index, idiosyncratic risk increases on average by $0.728 \%$ post SOX, compared to about $0.409 \%$ increase in systematic risk, and these differences are statistically significant. ${ }^{20}$

Columns (4)-(6) report results using the dummy variable, Entrenched. Following SOX, highly entrenched firms increased total risk by $2.3 \%$, relative to low entrenched firms. The increase in 
TAB LE 2 Differences in mean firm characteristics between high and low entrenched firms

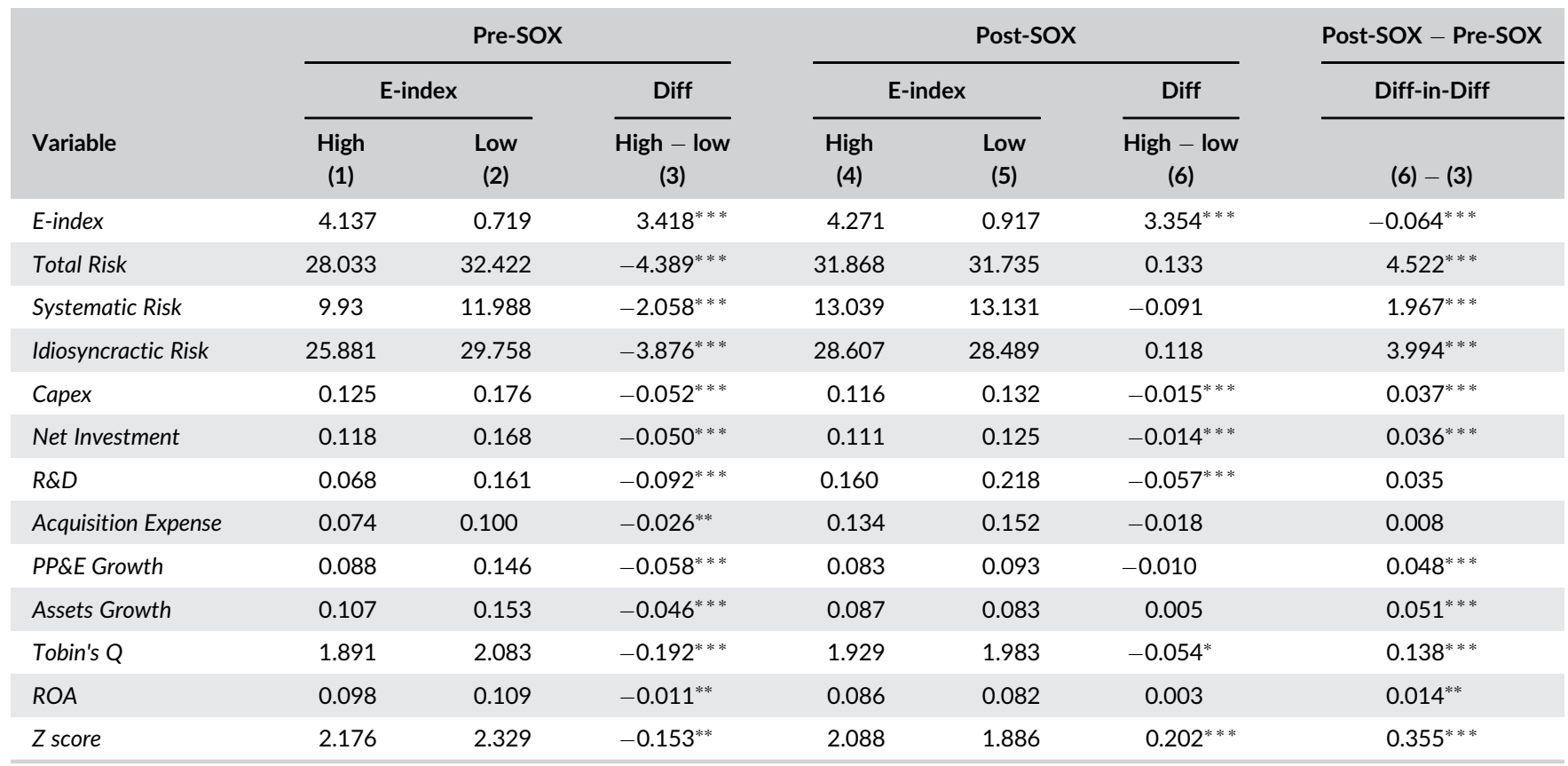

Note: This table shows the mean values for firm characteristics during the pre- and the post-SOX subperiods by entrenchment level and tests of the differences in means between firms with high and low entrenchment levels. Firms with high (low) managerial entrenchment are defined as those with E-index above 3 (E-index below 2) (columns "High" and "Low," respectively). Variable definitions are in Table A1. The sample period is 1992-2011. The number of firm-year observations over the pre-SOX (post-SOX) period is 613 and 1751 (1207 and 1463) for highly and low entrenched firms, respectively. ${ }^{*} p<10 \% .{ }^{* *} p<5 \% .{ }^{* * *} p<1 \%$.

systematic risk was significantly smaller compared to that in idiosyncratic risk (1.1\% vs. $1.9 \%)$. These changes are economically important as they represent increases of $8 \%(11 \%)(8 \%)$ of the median sample values for total (systematic)(idiosyncratic) risk. Taken together, this evidence supports Hypotheses 1.1 and 1.2 that SOX had a moderating effect on risk-reduction preferences of entrenched managers and induced them to increase corporate risk-taking primarily through refocusing on projects with higher idiosyncratic risk.

Table 4 examines whether the passage of SOX led to changes in the investment policy of firms with entrenched managers. Panel A reports results using E-index as an entrenchment proxy. The coefficient estimate on E-index in column (1) is negative $(-0.008)$, whereas the coefficient on the DiD-continuous term is positive (0.008). Both are significant at greater than $1 \%$. These results suggest that prior to SOX, highly entrenched managers invested less in capital relative to otherwise similar low entrenched firms. However, after the passage of SOX, entrenched managers increase capital expenditures, bringing them at par with their low entrenched counterparts. Economically, prior to SOX, a one-standard deviation increase in E-index (1.37) is associated with capital expenditures by $1.1 \%$ lower, representing a $10 \%$ decrease from the sample median. Following SOX, the same increase in E-index is associated with capital expenditures higher by $1.1 \%$. Hence, the combination of the pre- and post-SOX coefficients on E-index indicates no significant difference in capital investments of firms with different entrenchment levels after SOX. This result remains unchanged when I subtract asset disposals from capital expenditures as indicated by similar coefficient estimates on E-index and the DiD-continuous term in the regressions examining net investment (column (2)).

Thus, SOX appears to have reversed the previously conservative investment policy by entrenched managers and led to an increase in capital spending. Such effect of SOX could be due to a higher pressure imposed by more vigilant boards on entrenched managers to promote a more active investment policy. However, I interpret this result with caution as it could also be attributed to the mitigating effect of SOX on another agency conflict that is likely to happen in firms with entrenched managers-the reduction of costly effort. If entrenched managers have tendency to make fewer investments, perhaps due to their preference to exert less effort in general, then enhanced monitoring by boards after SOX could be expected to elicit more effort and hence higher investment. My tests examining investment variables are not able to differentiate between the two agency problems of managerial risk reduction and that of insufficient effort. Therefore, I view the investment results only as complementary to the tests explicitly examining changes in the risk-taking behavior.

Next, I examine the effect of SOX on acquisition spending and $R \& D$ of firms with entrenched managers (columns 3 and 4 of Table 4). However, the coefficients both on E-index and the DiD-continuous term are insignificant in these regressions. The insignificant results in acquisition expense regressions are not unexpected. Similarly to capital expenditure regressions, they do not differentiate between the two shareholder-manager conflicts-risk reduction, which is the focus here, and the reduction of effort by entrenched managers. If SOX was effective in moderating the "playing it safe" preference of entrenched 
TABLE 3 The effect of SOX and firm entrenchment on risk-taking

\begin{tabular}{|c|c|c|c|c|c|c|}
\hline & \multicolumn{6}{|c|}{ Dependent Variable $=$ Risk } \\
\hline SOX $\times$ E-index & $(0.237)$ & $(0.113)$ & $(0.215)$ & & & \\
\hline SOX $\times$ Entrenched & & & & $2.229^{* *}$ & $1.095^{* *}$ & $1.903^{* *}$ \\
\hline \multirow[t]{2}{*}{ E-index } & $-0.381^{* *}$ & $-0.146^{*}$ & $-0.341^{* *}$ & & & \\
\hline & $(0.165)$ & $(0.077)$ & $(0.152)$ & & & \\
\hline \multirow[t]{2}{*}{ Entrenched } & & & & -0.905 & -0.453 & -0.763 \\
\hline & & & & $(0.703)$ & $(0.352)$ & $(0.635)$ \\
\hline LN(Assets) & -0.091 & 0.053 & -0.114 & 0.165 & $0.170^{*}$ & 0.114 \\
\hline Market-to-Book Equity & $(0.128)$ & $(0.061)$ & (0.118) & $(0.167)$ & $(0.082)$ & (0.154) \\
\hline \multirow[t]{2}{*}{ Leverage } & -0.125 & -0.600 & 0.080 & 0.308 & -0.467 & 0.572 \\
\hline & $(0.128)$ & $(0.061)$ & $(0.118)$ & $(0.167)$ & $(0.082)$ & $(0.154)$ \\
\hline \multirow[t]{2}{*}{ LN(Firm Age) } & $-0.548^{* *}$ & -0.113 & $-0.555^{* *}$ & $-0.781^{* *}$ & -0.173 & $-0.788^{* *}$ \\
\hline & $(0.258)$ & $(0.130)$ & $(0.231)$ & $(0.368)$ & $(0.192)$ & $(0.329)$ \\
\hline \multirow[t]{2}{*}{ Constant } & $26.146^{* * *}$ & $9.550^{* * *}$ & $24.049^{* * *}$ & $24.854^{* * *}$ & $8.862^{* * *}$ & $22.952^{* * *}$ \\
\hline & $(1.065)$ & (0.528) & (0.973) & $(1.430)$ & $(0.738)$ & (1.299) \\
\hline Observations & 10,114 & 10,114 & 10,114 & 5,024 & 5,024 & 5,024 \\
\hline Adjusted $R^{2}$ & 0.577 & 0.553 & 0.561 & 0.611 & 0.576 & 0.596 \\
\hline
\end{tabular}

Note: This table shows results from the OLS regressions of firm risk-taking on SOX and managerial entrenchment levels. The dependent variables are total firm risk (columns 1 and 4), systematic risk (columns 2 and 5), and idiosyncratic risk (columns 3 and 6). Regressions in columns 1-3 use E-index to proxy for managerial entrenchment. Regressions in columns 4-6 proxy for entrenchment with an indicator variable Entrenched set to one if E-index is above 3, and equal to zero if $\mathrm{E}$-index is below 2. Variable definitions are in Table A1. All models include industry and year fixed effects and use standard errors clustered by firm (in parentheses). The sample period is 1992 to 2011.

${ }^{*} p<10 \% .{ }^{* *} p<5 \% .{ }^{* * *} p<1 \%$.

managers, it would reveal itself by firms with entrenched managers acquiring riskier targets, which will be picked up by the risk proxies, rather than by increasing spending on acquisitions per se.

The insignificant result for $R \& D$ spending is also not surprising given the possible conflicting hypotheses ( $3 \mathrm{~A}$ and $3 \mathrm{~B}$ ) for this investment type. On one hand, enhanced board monitoring due to SOX could pressure entrenched managers to invest more in risky and innovative projects that create higher long-term payoffs to shareholders. On the other hand, if entrenched managers have tendency to overinvest in R\&D as documented by prior studies (Giroud \& Mueller, 2010), then SOX could moderate this investment distortion by empowering boards to exercise greater control over entrenched managers. In fact, both effects could be present at the same time. However, the results suggest that none of the effects dominates either prior to or following SOX, and hence, over- or under-investment in $R \& D$ does not appear to be a major concern for firms with entrenched managers.

Further, in columns (5) and (6) of Table 4, I examine the changes in growth in assets and in property, plant, and equipment of firms with entrenched managers following SOX. The coefficient estimates on E- index are negative in these regressions, even though they are significant only for PP\&E growth. The DiD-continuous term attracts positive and significant coefficients of 0.011 and 0.010 for PP\&E and asset growth, respectively, suggesting that SOX led to a more rapid growth in the assets of entrenched firms relative to their peers.

Models in Panel B use a binary variable, Entrenched, to proxy for entrenchment and similarly support Hypothesis 2 that SOX was effective in inducing entrenched managers to increase capital investment and PP\&E growth to match those of the less entrenched peers.

\section{3 | Testing for firm value effects of SOX in firms with entrenched managers}

Hypothesis 4 predicts that if SOX was successful in moderating managerial risk-reduction preferences and conservative investment policy in entrenched firms, then firm value and operating performance will increase following the reform. The results in Table 5 are consistent with this hypothesis. Panel A uses E-index to proxy for entrenchment and shows significantly negative coefficients on E-index and 
TAB LE 4 The effect of SOX and firm entrenchment on corporate investment and asset growth

\begin{tabular}{|c|c|c|c|c|c|c|}
\hline & $\begin{array}{l}\text { Capex } \\
\text { (1) }\end{array}$ & $\begin{array}{c}\text { Net } \\
\text { investment } \\
\text { (2) }\end{array}$ & $\begin{array}{c}R \& D \\
(3)\end{array}$ & $\begin{array}{l}\text { Acquisition } \\
\text { expense } \\
\text { (4) }\end{array}$ & $\begin{array}{c}\text { PP\&E } \\
\text { growth } \\
(5)\end{array}$ & $\begin{array}{l}\text { Assets } \\
\text { growth } \\
\text { (6) }\end{array}$ \\
\hline \multicolumn{7}{|c|}{ Panel A: E-index as Entrenchment Proxy } \\
\hline \multirow[t]{2}{*}{ SOX $\times$ E-index } & $0.008^{* * *}$ & $0.007^{* * *}$ & -0.000 & -0.010 & $0.011^{* * *}$ & $0.01^{*}$ \\
\hline & $(0.003)$ & $(0.002)$ & $(0.007)$ & $(0.008)$ & $(0.004)$ & $(0.005)$ \\
\hline E-index & $-0.008^{* * *}$ & $-0.008^{* * *}$ & 0.000 & -0.003 & $-0.01^{* * *}$ & -0.004 \\
\hline Controls & Yes & Yes & Yes & Yes & Yes & Yes \\
\hline Observations & 9,963 & 9,963 & 10,052 & 10,052 & 10,050 & 10,114 \\
\hline Adjusted $R^{2}$ & 0.205 & 0.202 & 0.087 & 0.457 & 0.084 & 0.085 \\
\hline \multicolumn{7}{|c|}{ Panel B: Entrenched is set to one if E-index is above 3 and equal to 0 if $E$-index is below 2} \\
\hline Entrenched & $(0.009)$ & $(0.008)$ & $(0.021)$ & $(0.028)$ & $(0.012)$ & $(0.020)$ \\
\hline Controls & Yes & Yes & Yes & Yes & Yes & Yes \\
\hline Observations & 4,937 & 4,937 & 4,995 & 4,995 & 4,994 & 5,024 \\
\hline Adjusted $R^{2}$ & 0.247 & 0.246 & 0.081 & 0.486 & 0.112 & 0.111 \\
\hline
\end{tabular}

Note: This table shows results from the OLS regressions of firm investment, PP\&E growth, and asset growth on SOX and managerial entrenchment levels. Regressions in Panel A use E-index to proxy for managerial entrenchment. Regressions in Panel B proxy for entrenchment with an indicator variable Entrenched set to one if $\mathrm{E}$-index is above 3 and equal to 0 if $\mathrm{E}$-index is below 2. Variable definitions are in Table A1. All models include industry and year fixed effects and use standard errors clustered by firm (in parentheses). The sample period is 1992-2011.

${ }^{*} p<10 \% .{ }^{* *} p<5 \% .{ }^{* * *} p<1 \%$.

significantly positive coefficients on the DiD-continuous term in all regressions. These results suggest lower firm value, underperformance, and worse financial health in firms with higher entrenchment prior to SOX and improvements in all value and performance indicators in these firms after SOX. ${ }^{21}$ For example, prior to SOX a one-standard deviation increase in E-index leads to Tobin's $Q$ lower by 0.10 , which represents a $6.3 \%$ reduction from the median value. Passage of SOX, however, is associated with an increase in Tobin's $Q$ of 0.08 for an equivalent change in E-index. Combining preand post-SOX E-index coefficients shows that after SOX, there is no economically and statistically significant difference in Tobin's $Q$ across firms with different entrenchment levels.

The results are similarly supportive of Hypothesis 4 when using the binary measure of managerial entrenchment, Entrenched (Panel B of Table 5$).^{22}$

\section{4 | The impact of SOX and managerial entrenchment on financing decisions}

The results so far suggest that SOX was effective in attenuating the "playing it safe" behavior by entrenched managers. The next question that arises is how the increased risk-taking and investment in capital were financed by firms with entrenched managers post SOX. To answer it, I examine the changes in financial slack, dividend payout, net equity and debt issuances.
Prior studies argue that entrenched managers have higher than optimal preference for financial slack as it gives them more internal resources to spend and a cushion of safety when the company is not doing well (Dittmar \& Mahrt-Smith, 2007; Harford et al., 2008). I hypothesize that SOX mitigated the desire of entrenched managers for excessive slack and test this prediction by replacing the dependent variable in model (1) with the financial slack proxy. I define financial slack following Cleary (1999) as the sum of cash and short-term investments, half of inventory, $70 \%$ of accounts receivable, net of short-term loans, all scaled by net fixed assets. Column (1) in Table 6 shows a significantly negative coefficient estimate on the DiDcontinuous term $(-0.399, p<.000)$. This result is consistent with the hypothesis that post-SOX entrenched firms reduce cash holdings and inventory stock and take on more short-term debt financing, such as lines of credit, hence freeing resources for investment.

Next, I examine whether SOX led to changes in external uses and sources of funds in entrenched firms. Specifically, I ask whether entrenched managers free resources for investment in capital by cutting dividend payouts and by increasing equity or debt issues. I replace the dependent variable in model (1) with proxies for dividend payout, net equity issuance, and net debt issuance and report regression results in columns (2)-(4) in Table 6. Following SOX, entrenched firms indeed significantly cut dividend payments relative to otherwise similar low entrenched firms (coefficient estimate of -0.001 on $E$ index $\times$ SOX, $p<.000$ ). However, I do not find any significant changes in equity and debt issuances following SOX. The insignificant result 
TABLE 5 The effect of SOX on value and performance of entrenched firms

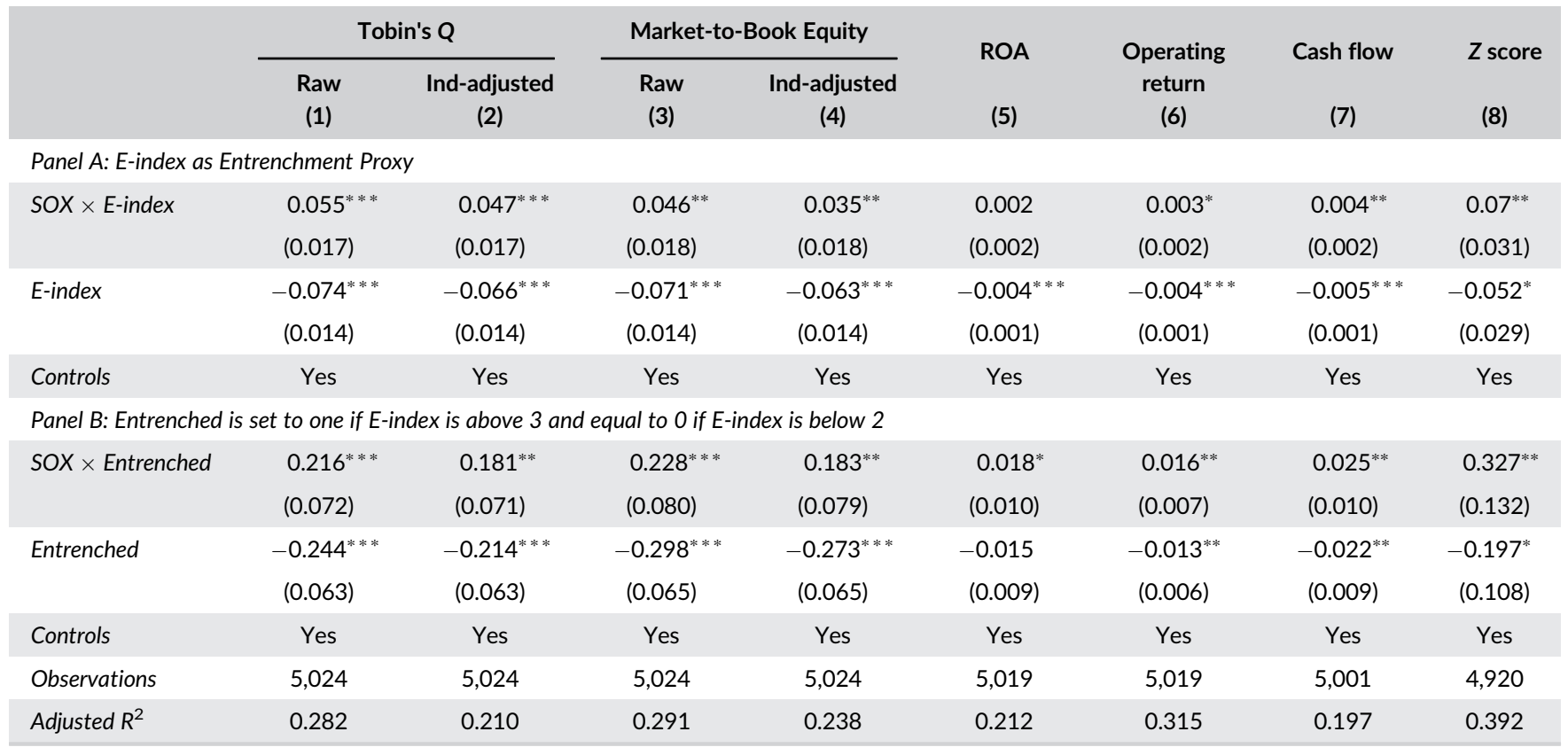

Note: This table shows results from the OLS regressions of firm value and operating performance on SOX and managerial entrenchment levels. Regressions in Panel A use E-index to proxy for managerial entrenchment. Regressions in Panel B proxy for entrenchment with an indicator variable Entrenched set to one if E-index is above 3 and equal to zero if E-index is below 2. Variable definitions are in Table A1. All models include industry and year fixed effects and use standard errors clustered by firm (in parentheses). The sample period is 1992-2011.

${ }^{*} p<10 \% .{ }^{* *} p<5 \% .{ }^{* * *} p<1 \%$.

TAB LE 6 The effect of SOX and entrenchment on short- and long-term uses and sources of funds

\begin{tabular}{|c|c|c|c|c|c|}
\hline & $\begin{array}{l}\text { Slack } \\
\text { (1) }\end{array}$ & $\begin{array}{l}\text { Dividends } \\
\text { (2) }\end{array}$ & $\begin{array}{l}\text { Equity issuance } \\
\text { (3) }\end{array}$ & $\begin{array}{l}\text { Debt issuance } \\
\text { (4) }\end{array}$ & $\begin{array}{l}\text { Effective cost of debt } \\
\text { (5) }\end{array}$ \\
\hline \multicolumn{6}{|c|}{ Panel A: E-index as Entrenchment Proxy } \\
\hline SOX $\times$ E-index & (0.119) & $(0.000)$ & $(0.001)$ & $(0.002)$ & (0.003) \\
\hline E-index & -0.042 & -0.000 & -0.001 & -0.001 & 0.002 \\
\hline \multicolumn{6}{|c|}{ Panel B: Entrenched is set to one if E-index is above 3 and equal to 0 if E-index is below 2} \\
\hline \multirow[t]{2}{*}{ SOX $\times$ E-index } & $-1.985^{* * *}$ & $-0.004^{* * *}$ & 0.005 & -0.007 & $-0.033^{* *}$ \\
\hline & $(0.763)$ & $(0.001)$ & (0.006) & $(0.009)$ & $(0.017)$ \\
\hline Entrenched & 0.274 & 0.001 & -0.005 & 0.003 & 0.002 \\
\hline Adjusted $R^{2}$ & 0.527 & 0.304 & 0.118 & 0.066 & 0.118 \\
\hline
\end{tabular}

Note: This table shows results from the OLS regressions of financing variables on SOX and managerial entrenchment levels. Regressions in Panel A use E-index to proxy for managerial entrenchment. Regressions in Panel B proxy for entrenchment with an indicator variable Entrenched set to one if E-index is above 3 and equal to 0 if E-index is below 2. Variable definitions are in Table A.1. All models include industry and year fixed effects and use standard errors clustered by firm (in parentheses). The sample period is 1992-2011.

${ }^{*} p<10 \% .{ }^{* *} p<5 \% .{ }^{* * *} p<1 \%$.

for debt issuances is surprising as prior studies show that SOX improved creditworthiness of firms, in particular those with poor corporate governance, and helped reduce borrowing costs (Andrade et al., 2014).
To understand further the impact of SOX on the borrowing of entrenched firms, I examine the cost of debt financing and present results in column (5) of Table 6. I find evidence of a lower effective cost of debt for entrenched firms after SOX. Specifically, after SOX, a 
one-standard deviation increase in E-index lowers the cost of debt by $1 \%$.

Using a binary variable, Entrenched, produces similar conclusions (Panel B of Table 6). Overall, the results in this section show that SOX led to positive changes in the financing policy of entrenched firms, such as reductions in financial slack and dividend payouts and a lower effective cost of debt. Cutting on some uses of funds (dividend payouts) and drawing on internal financing (lower slack and higher cash flow) likely allowed entrenched firms to support higher risk-taking and capital investments after the reform.

\section{5 | Robustness}

I conduct several additional tests to exclude alternative interpretations of results. First, I show that the results are not affected when controlling for CEO personal characteristics and incentives that could influence firm decisions and outcomes, such as CEO compensation delta and vega, overconfidence, tenure, age, and turnover (see Table IA.3 in the Internet Appendix). Second, I verify that firms with high and low levels of managerial entrenchment had similar pre-SOX trends in the main analysis variables (see Table IA.4 in the Internet Appendix). Third, the results are robust to holding the E-index fixed at its pre-reform level and to using alternative entrenchment and governance proxies, such as Staggered Board \& Poison Pill (SB\&PP) index by John and Kadyrzhanova (2008), the Governance index (G-index) by Gompers et al. (2003), and the takeover protection index (Takeover index) by Cain et al. (2017) (see Tables IA.5 and IA.8 in the Internet Appendix). Finally, I check that the results are not specific to the sample period, by repeating the main analyses for different and shorter pre-reform and post-reform periods around SOX and by omitting the years when the SOX regulation was phased in (see Table IA.7 in the Internet Appendix).

\section{5 | ECONOMIC MECHANISMS DRIVING POST-SOX CHANGES}

In this section, I explore specific economic mechanisms driving the postSOX changes in policies of entrenched firms. I begin with examining several key provisions of SOX, the impact of which can be isolated by identifying pre-SOX compliant and noncompliant firms, hence enabling identification of causality. Next, I investigate the impact of information acquisition cost on the main findings as it affects the effectiveness of monitoring by outsiders (Adams \& Ferreira, 2007; Harris \& Raviv, 2008). Finally, following up on the suggestive evidence from these analyses, I examine whether changes in compensation arrangements could be a major driver of increases in risk-taking and value in entrenched firms after SOX.

\section{1 | Pre-SOX compliance and entrenchment}

Which SOX provisions are driving the documented policy changes in entrenched firms? SOX was a comprehensive regulation and mandated many changes in corporate governance of public firms with the main purpose of better aligning the interests of corporate insiders with those of investors (Chhaochharia \& Grinstein, 2007; Linck et al., 2009). Most of the SOX provisions affected almost all U.S. firms, making it impossible to study their specific impact on the current findings. ${ }^{23}$ However, provisions related to board independence can be exploited to isolate the effects of SOX with respect to mandated changes in board structure.

To this end, I classify firms as either compliant ("compliers") or noncompliant ("non-compliers") with one of the SOX requirements prior to the passage of the reform: (1) the majority of independent directors; (2) fully independent audit committee; (3) fully independent compensation committee; and (4) fully independent nominating committee. For each of these definitions, I code an

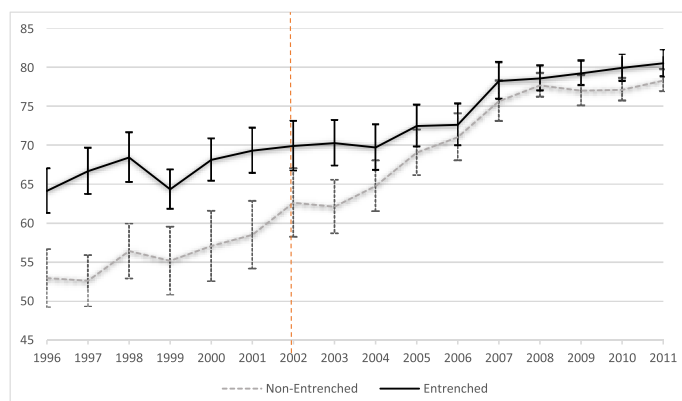

(a) Mean percentage of independent directors on the board

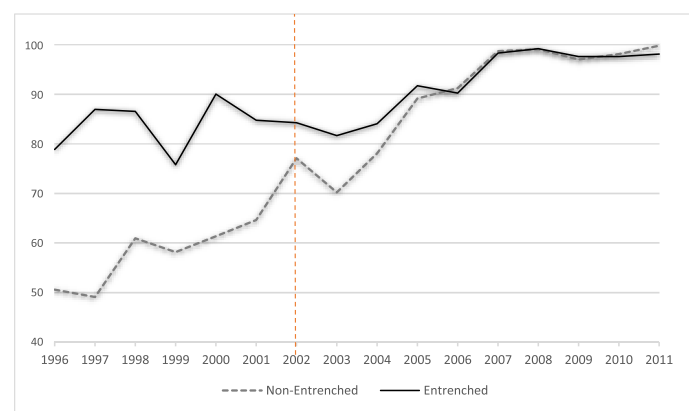

(b) Percentage of firms with independent board

FIGURE 1 Board independence. The figure plots the mean percentage of independent directors (Panel (a)) and the percentage of firms with majority of independent directors on the board (Panel (b)), separately for firms with non-entrenched and entrenched management. The vertical bars in Panel (a) are 95\% confidence bands. The sample consists of firm-year observations with available data on directors and boards from RiskMetrics and business segment, financial indicators, and return data from Compustat and CRSP. Firms with E-index greater than 3 are defined as entrenched and with E-index lower than 2 are non-entrenched [Colour figure can be viewed at wileyonlinelibrary.com] 
indicator variable Non-Comply equal to 1 when a firm is noncompliant with the respective requirement in 2001 and 0 otherwise. Data on independent directors and committee membership are from RiskMetrics. ${ }^{24}$

Figure 1 presents the evolution of the compliance with the board independence requirement separately for entrenched and nonentrenched firms during the pre- and post-SOX periods. Panel (a) plots the mean percentage of independent directors, along with the error bars showing the $95 \%$ confidence intervals. Panel (b) shows the percentage of firms with a majority-independent board. Throughout the pre-SOX period, entrenched firms had a significantly higher percentage of independent directors and, correspondingly, were significantly more compliant with the majority-independent board requirement. Only after the passage of SOX, compliance percentages for board independence start converging between the two groups. This finding is in line with prior literature documenting that firms with higher number of ATPs tend to have more independent boards and arguing that internal and external governance mechanisms may be substitutes (Gillan et al., 2011). However, my results show that pre-SOX, consistent with Gormley and Matsa (2016), more ATPs are associated with severe managerial entrenchment problems, such as risk-avoidance, even in the presence of an independent board. Hence, a higher percentage of independent directors in entrenched firms pre-SOX appears to be a mere window dressing rather than an evidence of stronger internal governance. Other factors are likely to play a significant role in determining the effectiveness of an independent board, for example, the independence of the oversight committees and information environment, both of which I explore later.

Figure 2 shows no difference in the percentage of entrenched and non-entrenched firms compliant with the requirements of fully independent audit, compensation, and nominating committees throughout the sample period (Panels (a)-(c), respectively). Thus, although prior to SOX, entrenched firms had a significantly higher percentage of independent directors on their boards, they did not set up fully independent board committees more often. This graphical evidence suggests it is unlikely that the changes in entrenched firms are driven by the majority independent board requirement. Nonetheless, I continue examining the role of all four SOX independence provisions in mitigating risk-avoidance behavior in entrenched firms.

To evaluate the impact of each of the four provisions, I add the second treatment level (NonComply) to the DiD model (1) and estimate the triple difference (DiDiD) specification ${ }^{25}$ :

$$
\begin{aligned}
Y_{i, t} & =\phi_{0}+\phi_{1} \text { SOX } \text { Entrenched }_{i, t-1}+\phi_{2} \text { SOX } \times \text { NonComply }_{i} \\
& +\phi_{3} \text { SOX } \times \text { Entrenched }_{i, t-1} \times \text { NonComply }_{i} \\
& +\phi_{4} \text { Entrenched }_{i, t-1} \times \text { NonComply }_{i}+\phi_{5} \text { Entrenched }_{i, t-1} \\
& +\phi_{6} \text { NonComply }_{i}+\theta X_{i, t-1}+\gamma_{j}+\gamma_{t}+\varepsilon_{i, t},
\end{aligned}
$$

where $Y_{i, t}$ takes the value of one of the analyzed outcome variables, Risk $_{i, t}$, Investment ${ }_{i, t}$, FirmValue ${ }_{i, t}$, or Performance ${ }_{i, t}$. NonComply $y_{i}$ is an indicator variable that equals 1 if firm $i$ is noncompliant with the specific board independence requirement at year-end 2001 and 0 otherwise, and all other variables are as defined in model (1). Firms still (a) Percentage of firms with fully independent audit committee

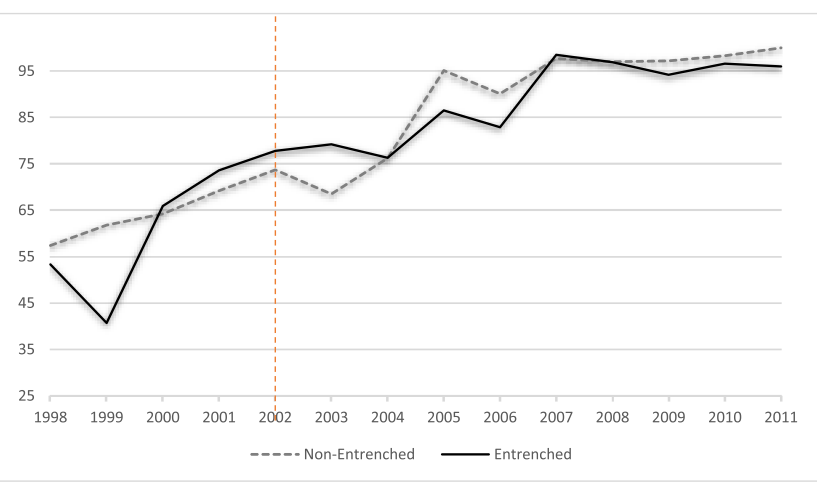

(b) Percentage of firms with fully independent compensation committee

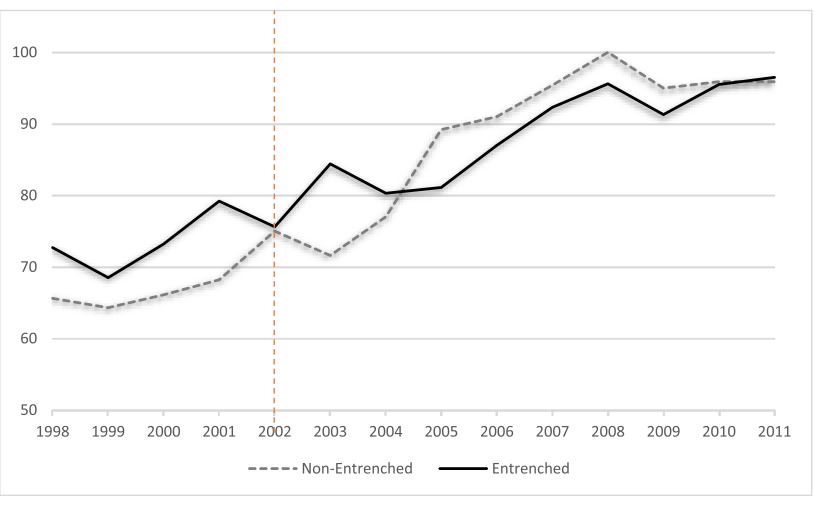

(c) Percentage of firms with fully independent nominating committee

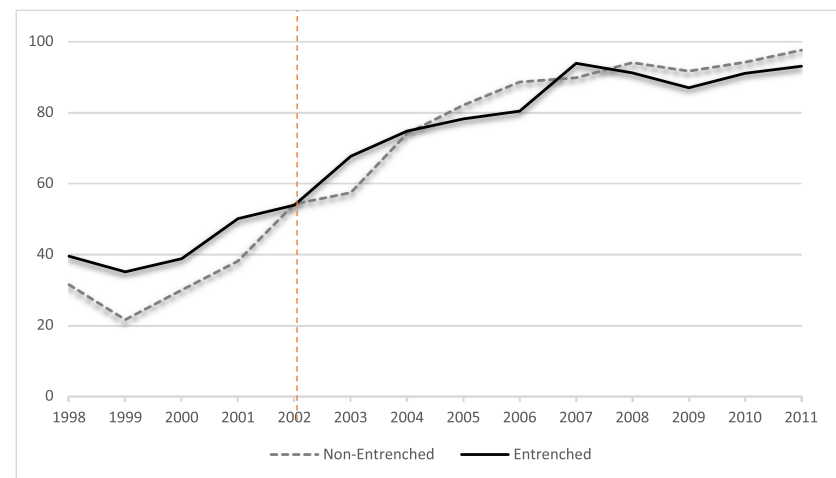

FIG URE 2 Committee independence. The figure plots the percentage of firms with fully independent audit, compensation, and nominating committees (Panels (a)-(c), respectively), separately for firms with non-entrenched and entrenched management. The sample consists of firm-year observations with available data on directors and boards from RiskMetrics and business segment, financial indicators, and return data from Compustat and CRSP. Firms with E-index greater than 3 are defined as entrenched and with E-index lower than 2 are non-entrenched [Colour figure can be viewed at wileyonlinelibrary.com]

noncompliant with the respective requirement in 2005 are dropped from further analyses. The group of interest is the post-SOX noncompliant entrenched firms. The SOX effect for this group is given by the combination of coefficients $\phi_{1}+\phi_{2}+\phi_{3}$. 
Table 7 reports results for the noncompliance with the requirements of the majority independent board (Panel A) and full independence of audit, compensation, and nominating committees (Panels B-D). For brevity, I present only the combined coefficient estimates for the noncompliant entrenched post-SOX group. Table IA.9 in the Internet Appendix reports the full estimation results. The base group is the pre-SOX non-entrenched compliers.

For the first two independence requirements, majorityindependent board and fully independent audit committee (Panels A and $B$ ), entrenched noncompliers do not exhibit significant changes in their risk-taking behavior and performance relative to the base group. Only the effects for capital expenditure and PP\&E growth are significantly positive for this group of firms. However, the post-SOX changes are striking for the compliance with the requirement of the fully independent compensation committee (Panel C). Entrenched firms that were noncompliant with this SOX provision prior to the reform show significant increases in their risk-taking, investment, and firm value post-SOX, relative to the base group. ${ }^{26}$ For example, entrenched firms previously noncompliant with the compensation committee independence requirement increase their total risk by $6.75 \%$, capital spending by $5.20 \%$, and Tobin's Q by 0.45 following
SOX. These numbers are economically important and represent increases of $25 \%, 47 \%$, and $28 \%$ from their respective sample median values. Results based on the noncompliance with the full independence of the nominating committee (Panel D) are weaker and similar to those for the first two requirements in Panels $A$ and $B$. The effects are significant only for investment variables and marginally significant for systematic risk.

Thus, the overall results appear to be driven by entrenched firms that were pre-SOX noncompliant with the requirement of a fully independent compensation committee. I conclude that, having a fully independent compensation committee appears to be more important for mitigating managerial entrenchment than appointing a majority independent board or fully independent audit and nominating committees.

\subsection{The impact of information acquisition costs}

Prior studies show that the effectiveness of boards depends on the cost of information acquisition. Because outside directors typically have limited access to firm-specific information and high costs in

TAB LE 7 Triple difference models - Noncompliance with board and committees independence requirements

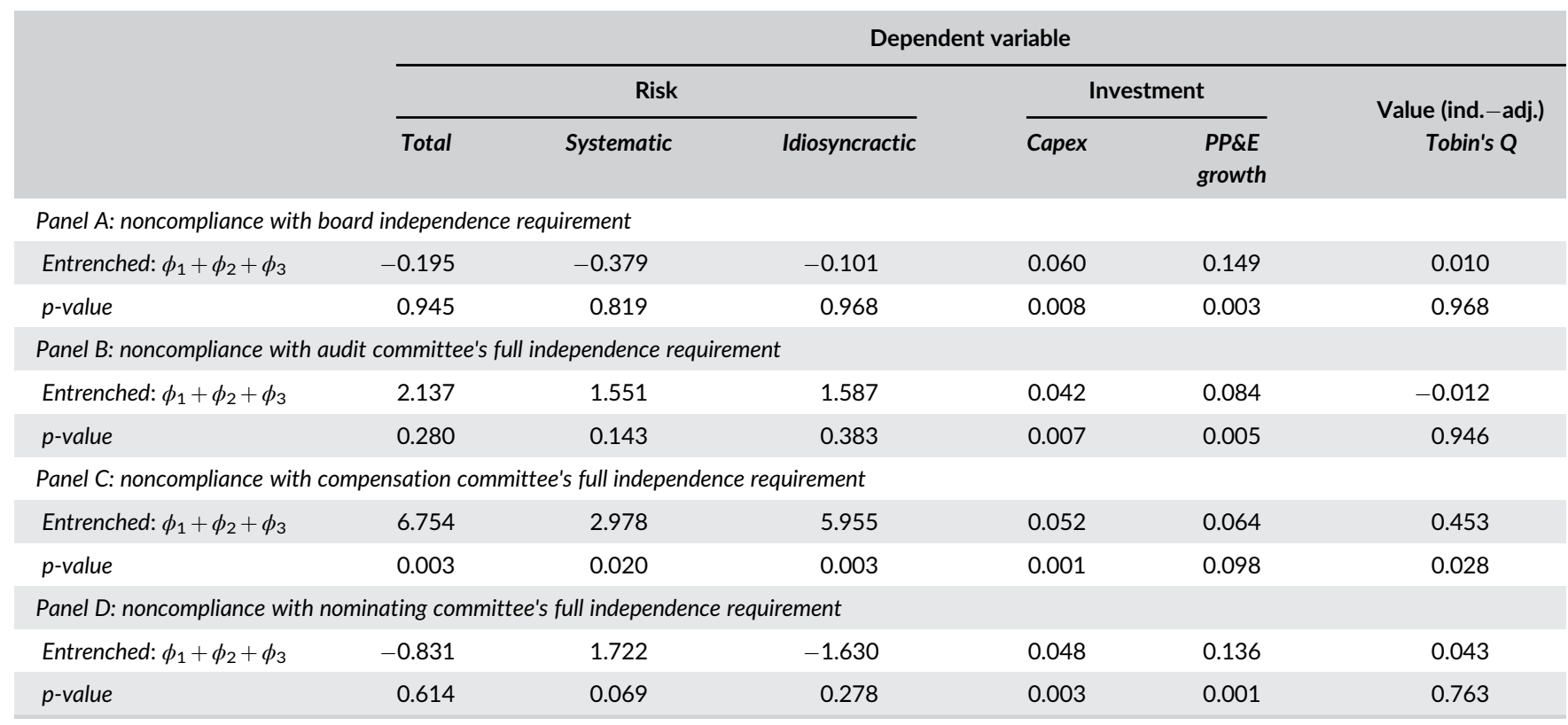

Note: This table reports coefficient estimates of OLS regressions as in model (4) of firm risk-taking, investment, and value on managerial entrenchment, post-SOX indicator, and an indicator for the noncompliance with one of the SOX board independence requirements:

$$
\begin{aligned}
Y_{i, t} & =\phi_{0}+\phi_{1} \text { SOX } \times \text { Entrenched }_{i, t-1}+\phi_{2} \text { SOX } \text { NonComply }_{i}+\phi_{3} \text { SOX } \times \text { Entrenched }_{i, t-1} \times \text { NonComply }_{i} \\
& +\phi_{4} \text { Entrenched }_{i, t-1} \times \text { NonComply }_{i}+\phi_{5} \text { Entrenched }_{i, t-1}+\phi_{6} \text { NonComply }_{i}+\theta X_{i, t-1}+\gamma_{j}+\gamma_{t}+\varepsilon_{i, t},
\end{aligned}
$$

$Y_{i, t}$ is a proxy for risk, investment, or firm value. Entrenched is an indicator variable set to 1 if E-index is above 3 and equal to 0 if E-index is below 2. SOX equals one for post-SOX period, 2002-2011. NonComply is an indicator variable that equals 1 if a firm is noncompliant with the specific board independence requirement at year-end 2001 and 0 otherwise. All other variables are defined in Table A1. All models include industry and year fixed effects and use standard errors clustered by firm. To preserve space, the table only reports the effect for the post-SOX group of noncompliant entrenched firms represented by the sum of coefficients $\phi_{1}, \phi_{2}$, and $\phi_{3}$, and the $p$-value for the $t$-test that this coefficient combination is equal to 0 . Panels $A$-D provide, respectively, the results for the noncompliance with requirements of the majority independent board, full independence of audit committee, full independence of compensation committee, and full nominating of audit committee. The sample period is 1996-2011 in Panel A and 1998-2011 in Panels B-D. 
evaluating its reliability, monitoring by these directors is more effective in firms operating in low information asymmetry environments (Adams \& Ferreira, 2007; Duchin et al., 2010). Given that improvements in board monitoring were at the core of the SOX reform, I examine the role of information cost in the policy changes in entrenched firms.

I follow Duchin et al. (2010) in constructing proxies of information acquisition cost using IBES data on analysts' following and quarterly earnings forecasts. I use the number of analysts who issued forecasts about a firm in a year, expressed as a natural logarithm, the dispersion of analyst forecasts, and the analyst forecast error. Table A1 provides further details on these variables. Information acquisition costs decrease in the number of analysts and increase in analyst forecast dispersion and errors. I also construct an information cost index defined as a mean of the firm's percentile rankings for each of the three above measures and scaled to range from 0 (low cost) to 1 (high cost). ${ }^{27}$

I explore the impact of the information acquisition cost in three stages. First, I repeat the main regressions controlling for information cost and find no change in the main results (see Tables IA.10 and IA.11 in the Internet Appendix). Second, I run the main DiD specification separately for firms operating in low and high information cost environments and present results in Panels $A$ and $B$, respectively, of
Table 8. Low information cost group is defined as firms with Information Cost Index below the sample median in a given year. ${ }^{28}$ I expect a stronger effect of SOX on policies of entrenched firms with lower outsiders' cost of information acquisition. All coefficient estimates on the DiD-continuous term in Panel A are significantly positive. Importantly, they are at least double those reported in Tables 3 and 4 for the entire group of entrenched firms, suggesting the effect is coming entirely from the low information cost subgroup. For example, post-SOX this subgroup increases total risk and capital spending by $4.5 \%$ and $3.3 \%$, respectively, while the corresponding values from Tables 3 and 4 were $2.23 \%$ and $0.8 \%$. In contrast, the high information cost subgroup of entrenched firms does not exhibit a similar behavior as indicated by insignificant DiD coefficients in all regressions in Panel B. Moreover, the Chow test shows that the differences in DiD coefficients between low and high information cost subgroups of entrenched firms are significant at better than $1 \%$ level in all, except for Tobin's Q, regressions. These results are consistent with the expectation that only entrenched firms operating in low information cost environment increase risk-taking, investment, and firm value post-SOX.

Third, I re-run the triple difference (DiDiD) regressions on the sample of compliers and noncompliers separately for firms operating in low and high information cost environments. I focus only on the pre-SOX noncompliance with the requirement of a fully independent

TABLE 8 The impact of information cost - Difference-in-differences models

\begin{tabular}{|c|c|c|c|c|c|c|}
\hline & \multicolumn{6}{|c|}{ Dependent variable } \\
\hline & $\begin{array}{l}\text { Total } \\
\text { (1) }\end{array}$ & $\begin{array}{c}\text { Systematic } \\
\text { (2) }\end{array}$ & $\begin{array}{c}\text { Idiosyncractic } \\
\text { (3) }\end{array}$ & $\begin{array}{l}\text { Capex } \\
\text { (4) }\end{array}$ & $\begin{array}{l}\text { PP\&E } \\
\text { Growth } \\
\text { (5) }\end{array}$ & $\begin{array}{c}\text { Tobin's } Q \\
\text { (6) }\end{array}$ \\
\hline \multicolumn{7}{|c|}{ Panel A: low information cost } \\
\hline SOX $\times$ Entrenched & $(1.296)$ & $(0.651)$ & $(1.167)$ & $(0.013)$ & $(0.023)$ & $(0.093)$ \\
\hline \multirow[t]{2}{*}{ Entrenched } & $-3.295^{* * *}$ & $-1.722^{* * *}$ & $-2.797^{* * *}$ & $-0.036^{* * *}$ & $-0.042^{*}$ & -0.120 \\
\hline & $(1.090)$ & $(0.554)$ & $(0.984)$ & $(0.012)$ & $(0.025)$ & $(0.083)$ \\
\hline Controls & Yes & Yes & Yes & Yes & Yes & Yes \\
\hline Observations & 2,813 & 2,813 & 2,813 & 2,771 & 2,795 & 2,813 \\
\hline SOX $\times$ Entrenched & (2.131) & $(1.077)$ & (1.969) & $(0.027)$ & $(0.032)$ & $(0.245)$ \\
\hline \multirow[t]{2}{*}{ Entrenched } & 2.591 & $1.582^{*}$ & 2.199 & 0.001 & -0.001 & -0.321 \\
\hline & (1.778) & $(0.863)$ & $(1.651)$ & $(0.022)$ & $(0.027)$ & $(0.214)$ \\
\hline Controls & Yes & Yes & Yes & Yes & Yes & Yes \\
\hline Observations & 938 & 938 & 938 & 918 & 936 & 938 \\
\hline Adjusted $R^{2}$ & 0.650 & 0.611 & 0.640 & 0.233 & 0.129 & 0.285 \\
\hline
\end{tabular}

Note: This table repeats selected regressions of firm risk-taking, investment, and value on SOX and managerial entrenchment levels as in Tables 3-5, separately for firms operating in low information cost (Panel A) and high information cost (Panel B) environments. For the sake of brevity, only regressions using an indicator variable Entrenched are reported. It is set to 1 if $\mathrm{E}$-index is above 3 and equal to 0 if E-index is below 2 . Variable definitions are in Table A1. All models include industry and year fixed effects and use standard errors clustered by firm (in parentheses). The sample period is $1992-2011$.

${ }^{*} p<10 \% .{ }^{* *} p<5 \% .{ }^{* * *} p<1 \%$. 
TABLE 9 The impact of information cost (IC) - Triple difference models

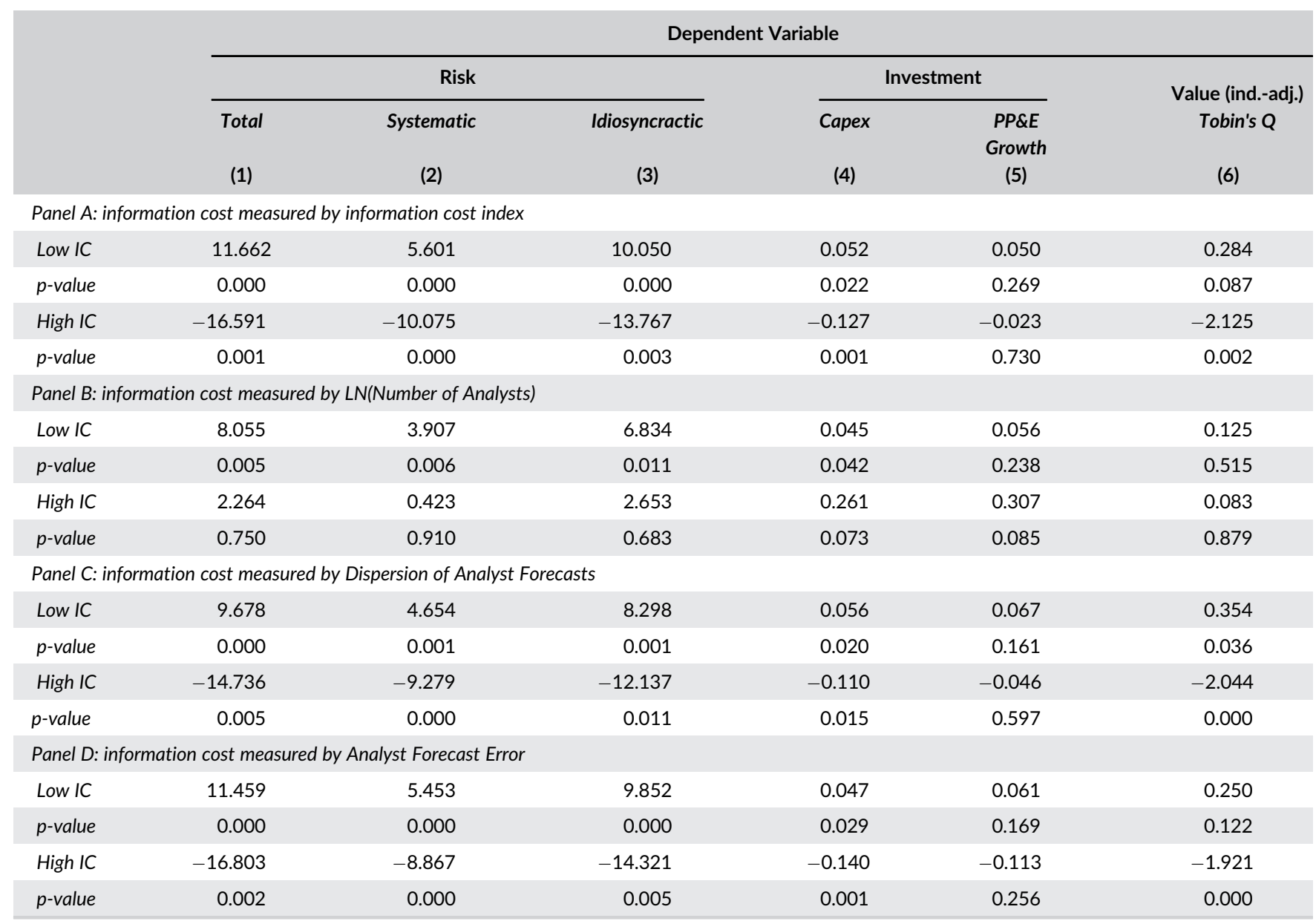

Note: This table reports coefficients estimates of OLS regression as in model (4), separately for firms operating in low and high information cost environments (Low IC and High IC, respectively).

$$
\begin{aligned}
Y_{i, t}= & \phi_{0}+\phi_{1} \text { SOX } \text { Entrenched }_{i, t-1}+\phi_{2} \text { SOX } \times \text { NonComply }_{i}+\phi_{3} \text { SOX } \\
& \times \text { Entrenched }_{i, t-1} \times \text { NonComply }_{i} \\
& +\phi_{4} \text { Entrenched }_{i, t-1} \times \text { NonComply }_{i}+\phi_{5} \text { Entrenched }_{i, t-1} \\
& +\phi_{6} \text { NonComply }_{i}+\theta X_{i, t-1}+\gamma_{j}+\gamma_{t}+\varepsilon_{i, t},
\end{aligned}
$$

$Y_{i, t}$ is a proxy for risk, investment, or firm value. Entrenched is an indicator variable set to 1 if E-index is above 3 and equal to 0 if E-index is below 2. SOX equals 1 for post-SOX period, 2002-2011. NonComply is an indicator variable that equals 1 if a firm is noncompliant with the specific board independence requirement at year-end 2001 and 0 otherwise. All variables are defined in Table A1. All models include industry and year fixed effects and use standard errors clustered by firm. To preserve space, the table only reports the effect for the post-SOX group of noncompliant entrenched firms represented by the sum of coefficients $\phi_{1}, \phi_{2}$, and $\phi_{3}$, and the $p$-value for the $t$-test that this coefficient combination is equal to 0 . Information cost is measured by Information Cost Index in Panel A, by LN(Number of Analysts) in Panel B, by Dispersion of Analyst Forecasts, and by Analyst Forecast Error in Panel D. The sample period is 1992-2011.

compensation committee given the evidence in Section 5.1 that the main results can be attributed to this SOX provision. Table 9 reports the results. For the sake of brevity, I only report the combined postSOX coefficient estimates for the group of entrenched noncompliers $\left(\phi_{1}+\phi_{2}+\phi_{3}\right.$ in model 4). Panels A-D show the results using one of the four proxies for information acquisition cost. Regardless of the information cost proxy used, significant increases in risk, investment, and firm value post-SOX occur only in the group of entrenched noncompliers operating in a low information cost environment. Similarly to the previous table, the combined effect for this subgroup is almost double the magnitude for the entire group of entrenched noncompliers (compare with Panel $\mathrm{C}$ of Table 7). For example, splitting the groups on the basis of Information Cost Index (Panel A) shows that, following SOX, the low information cost group of entrenched firms increases its total risk by $11.7 \%$, capital spending by $5.2 \%$, and Tobin's $Q$ by 0.29 . Respective values for the post-SOX high information cost group of entrenched firms are significant decreases of $16.6 \%, 12.7 \%$, and 2.13 . 
Taken together, these results confirm that the requirement to have a fully independent compensation committee produces tangible benefits only in the policies of entrenched firms with less costly information acquisition by outside directors.

\subsection{Are Post-SOX changes compensation-driven?}

What is the channel through which a fully independent compensation committee can engender policy changes in entrenched firms? This is the final question I explore. The board's compensation committee plays an important role in overseeing and setting managerial pay and hence in providing incentives and aligning the interests of managers with those of investors (Adams \& Ferreira, 2007). At the same time, prior studies show that having insiders, even one, on the compensation committee negatively impacts CEO pay arrangements and subsequently firm value (Newman \& Mozes, 1999). Hence, a fully independent compensation committee mandated by SOX can be expected to adjust any existing suboptimal pay practices to realign managerial incentives. Naturally, these adjustments are more likely to happen in firms with pay practices preferential towards the CEO, that is, those with higher entrenchment.
I test this conjecture by examining the impact of SOX on several CEO compensation and incentive proxies. The first two proxies are CEO Stock Ownership and CEO Option Ownership, defined, respectively, as the value of CEO's stock holdings and that of option holdings in total firm market value. The other two proxies are CEO portfolio delta, Delta, and option portfolio vega, Vega, defined as explained in Table A1. Higher CEO's stock and option ownership as well as compensation delta better align their interests with those of investors, while higher stock option holdings and vega create preference for riskier projects (Coles et al., 2006; Hall \& Liebman, 1998).

Panel A of Table 10 presents the DiD results for the full sample. The coefficient estimate on Entrenched is negative in the CEO stock ownership, option ownership, and delta regressions, although it is insignificant in CEO option ownership regressions. This result suggests that prior to SOX, pay arrangements in entrenched firms provided weaker alignment of shareholder-manager interests compared to firms with less entrenched management. In contrast, the same regressions show positive and significant coefficients on the DiD-continuous term, indicating an increase in CEO's stake in the firm and a stronger alignment of interests after SOX. I do not find any significant changes in CEO's compensation vega. This result is not surprising given that most of the post-SOX period overlaps with the period following the FAS 123R rule implemented in

TABLE 10 The effect of SOX on compensation of entrenched firms

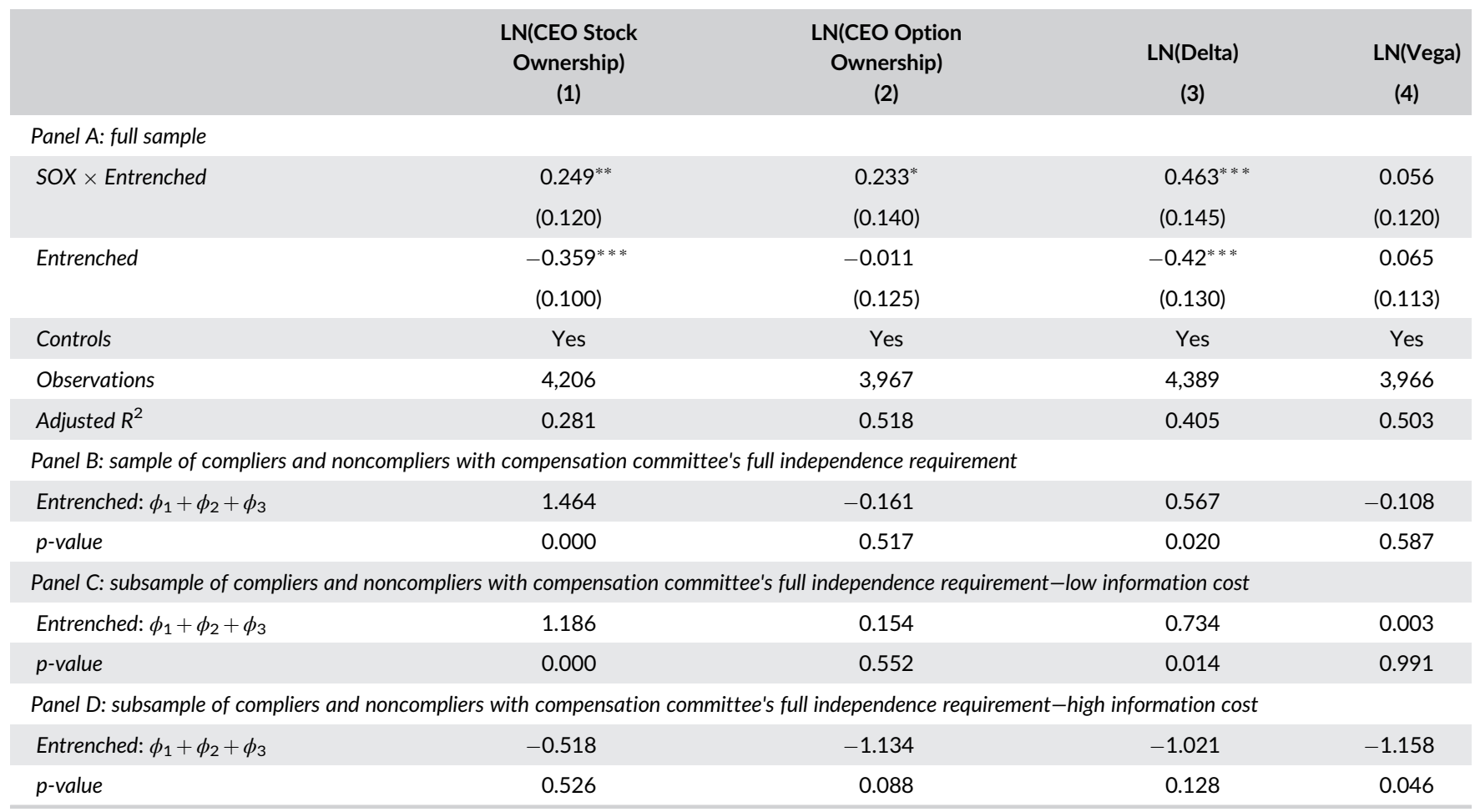

Note: This table reports OLS regressions of compensation components and incentives on SOX and managerial entrenchment. Panel A presents results for difference-in-differences models run on the full sample as in Equation (1). Panel B reports results of triple difference OLS regressions as in model (4) using a sample of pre-SOX compliers and noncompliers with the requirement of the full independence of compensation committee. Panels $C$ and $D$ repeat regressions in Panel B separately for subsamples of firms operating in low and high information cost environments, respectively. Panels B-D only report the effect for the post-SOX group of noncompliant entrenched firms represented by the sum of coefficients $\phi_{1}, \phi_{2}$, and $\phi_{3}$ and the $p$-value for the $t$-test that this coefficient combination is equal to 0 . All variables are defined in Table A1. All models include industry and year fixed effects and use standard errors clustered by firm. The sample period is 1992-2011 and 1998-2011 in Panels B-D.

${ }^{*} p<10 \% .{ }^{* *} p<5 \% .{ }^{* * *} p<1 \%$. 
2005. This regulation required expensing the fair value of managerial stock options at the grant date and hence significantly reduced the attractiveness of option grants in managerial pay packages. This result is consistent with a vast literature showing an overall decrease in compensation vega after the passage of FAS 123R (e.g., Hayes et al., 2012).

Panel B of Table 10 reports the results of the DiDiD compensation tests using compliers and noncompliers with the compensation committee's full independence requirement. As before, I report only the combined coefficient showing the effect for the post-SOX entrenched noncompliers. This group experienced significant increases in CEO stock ownership and compensation delta but not in CEO option ownership and vega.

Panels $C$ and $D$ of Table 10 repeat triple difference compensation tests for the subsamples of compliers and noncompliers split into firms operating in low and high information cost environments. Consistent with prior results, I find that realignment of incentives happens only among the pre-SOX noncompliant entrenched firms operating in a low information cost environment because significant increases in CEO's stock ownership and compensation delta happen only in this subgroup. Changes in the pay practices of this subgroup of firms are driving increases in risk-taking, investment, and firm value post SOX.

\section{6 | CONCLUSIONS}

I document a disciplining effect of the Sarbanes-Oxley Act on entrenched management. Following the passage of this governance reform, highly entrenched firms increase their firm risk and capital investments above or at par with those of their otherwise similar low entrenched counterparts. These changes are associated with increases in firm value, operating performance, and improved financial health. I find evidence that following SOX firms with entrenched managers reduce their financial slack, cut dividend payouts, and lower their cost of debt, which could free up internal and external resources to finance increased risk-taking and capital spending.

The specific mechanism responsible for the uncovered positive changes in the policies of entrenched firms is the SOX requirement of a fully independent compensation committee. This provision induced beneficial adjustments in the pay practices of previously noncompliant entrenched firms. Following SOX, CEOs of entrenched firms are rewarded with more extrinsic financial rewards, such as equity, which strengthens their incentives to pursue riskier investments that are in the long-term interests of investors. Importantly, these post-SOX policy changes take place only in entrenched firms with lower information asymmetries, that is, when it is easier and less costly for outside directors to become informed about the firm.

I conclude that tying compensation to performance is an effective mechanism to alleviate the managerial risk-avoidance problem. However, to abate this problem in firms with high managerial entrenchment, the compensation committee needs to be fully independent, hence free from the influence of entrenched management, and to have access to timely and accurate information necessary to design optimal remuneration policies.

\section{NOTES}

${ }^{1}$ Managerial "playing it safe" incentives have been widely studied in the theoretical finance literature. See, for example, Holmström and Costa (1986), Lambert (1986), and Hirshleifer and Thakor (1992).

2 The same governance shock, among others, was used by Linck et al. (2009), Duchin et al. (2010), and Banerjee et al. (2015).

${ }^{3}$ This approach is similar to Banerjee et al. (2015), who examine the impact of SOX on firm policies conditional on managerial overconfidence, exploiting the relative time stability of this managerial trait.

${ }^{4} \mathrm{E}$-index is 1 and 3, respectively, for firms at the 25th and 75th percentile of the E-index distribution.

${ }^{5}$ The distinction between managerial entrenchment that I study and overconfidence studied by Banerjee et al. (2015) is also apparent in the data. There is no significant correlation between my proxy for entrenchment and that for overconfidence used by Banerjee et al. (2015). Moreover, all results remain unchanged after controlling for CEO overconfidence.

${ }^{6}$ The Sarbanes-Oxley Act was signed into law on July 30, 2002. For summaries of this legislation, see Kim (2003) and Chhaochharia and Grinstein (2007).

${ }^{7}$ NYSE required full independence of the three key committees, whereas NASDAQ required full independence of the audit committee only and that the majority of members of compensation and nominating committees are independent.

${ }^{8}$ Similar view and empirical strategy are taken by John et al. (2016), who show that the incremental benefit of external corporate governance mechanisms is concentrated in firms with high cash holdings, that is, with potentially more severe agency conflicts.

${ }^{9}$ I treat 2002 as the first year of SOX since it is the year when the main reform had begun with the passage of the Sarbanes-Oxley Act. In the robustness tests, I check that the results are not sensitive to the definition of the post-SOX period.

${ }^{10}$ I use the specification with fixed firm effects only as a complementary one since the entrenchment proxy does not vary much over time, and therefore, this specification may have low explanatory power.

${ }^{11}$ The sample period starts in 1992 because this is the first year the data are available in ExecuComp database, which I use to construct CEO characteristics for later analysis. Similarly to Linck et al. (2008) and Banerjee et al. (2015), I do not require firms to survive during a specific number of years around SOX not to introduce survivorship bias.

12 As noted by Armstrong and Vashishtha (2012), this definition of systematic risk, instead of a more common beta measure, facilitates its comparability with the idiosyncratic risk proxy and allows for a direct test of hypothesis $1 \mathrm{~B}$.

${ }^{13}$ Compared to Armstrong and Vashishtha's (2012) risk proxies, my proxies use a finer definition of industries at the four-, rather than two-digit SIC level. In addition, my approach incorporates only the information about managerial choices in the current year, which improves the relevance and accuracy of the risk estimate.

${ }^{14}$ From 1990 to 2006, RiskMetrics data necessary for the construction of the E-index are provided only for years 1990, 1993, 1995, 1998, 2000 2002, 2004, and 2006. I filled the missing years with the data for the most recent year that has available data. Prior studies also note the stickiness of the governance data during this period and similarly fill the data (Gompers et al., 2003; Bebchuk et al., 2009; Chang \& Zhang 2015).

${ }^{15}$ A detailed description of these provisions can be found in Gompers et al. (2003) and Bebchuk et al. (2009).

${ }^{16}$ Further examining firm-level changes in E-index between the publication dates revealed no change for about $62 \%$ of firm-year observations, with a mere $2 \%$ of firm-year observations having changes of more than two points from the previous publication year. Chang and Zhang (2015) 
report similar percentage of no changes in E-index between the publication dates (77.8\%) during the period they examine (1990-2007).

17 Tables IA.1 and IA.2 in the Internet Appendix present summary statistics for the analysis variables and their mean values for each index level during the pre- and post-SOX periods. Both tables suggest a strong negative correlation between entrenchment and firm risk prior to, but not after, the SOX reform.

18 The main results use industry and year fixed effects and remain unchanged if industry fixed effects are replaced with firm fixed effects. These robustness checks are reported in Table IA.6 in the Internet Appendix.

${ }^{19}$ Combining coefficients on E-index and the DiD term, SOX $\times$ E-index, produces a significantly positive value $(1.41 \%, p<.01$ for firms at the 75th percentile of the distribution), which may suggest that the overall level of risk-taking became greater in firms with higher levels of entrenchment. One explanation for this finding is a likely higher degree of non-co-opted independence in firms with entrenched managers due to greater board independence in these firms pre-SOX and similar levels of CEO turnover post-SOX, relative to firms with low entrenchment.

20 The coefficient estimates on firm-specific controls are generally consistent with expectations and prior literature. Risk-taking is increasing in growth opportunities and decreasing in firm age and has ambiguous relationship with firm size and financial leverage.

${ }^{21}$ Note that distress risk of entrenched firms is expected to increase after SOX along with the increase in risk-taking. I confirm this conjecture by running the same model as in equation (1), replacing the dependent variable with distress risk, proxied by the Merton (1974) twelve-month ahead default probability.

22 In none of the regressions the combined pre- and post-SOX coefficients (Entrenched + SOX $\times$ Entrenched) are statistically significant at any conventional levels, suggesting no difference in the firm value and performance across highly and low entrenched firms post SOX.

${ }^{23}$ SOX applied to all publicly listed firms in the United States except for foreign issuers, passive business organizations, controlled firms, and firms in bankruptcy.

24 Data on independent directors are available from 1996, data on committee membership start from 1998.

${ }^{25}$ I use the indicator variable Entrenched in all DiDiD models to ease interpretation of results. They remain unchanged, however, when the continuous entrenchment proxy, E-index, is used.

${ }^{26}$ Note that significantly positive combined coefficient estimate, $\phi_{1}+\phi_{2}+$ $\phi_{3}$, does not necessarily imply that the group of entrenched noncompliers had higher levels of examined outcome variables post-SOX, relative to the base group. It only suggests that this group experienced a significant change (increase) in the outcome variable compared to the base group.

${ }^{27}$ For the number of analysts, the ranking is reversed.

${ }^{28}$ Results are qualitatively similar for the other three information cost proxies (untabulated)

\section{DATA AVAILABILITY STATEMENT}

The data that support the findings of this study are available from the corresponding author upon reasonable request.

\section{ORCID}

Oksana Pryshchepa (D) https://orcid.org/0000-0003-3785-8556

\section{REFERENCES}

Acharya, V. V., \& Bisin, A. (2009). Managerial hedging, equity ownership, and firm value. RAND Journal of Economics, 40, 47-77. https://doi.org/ 10.1111/j.1756-2171.2008.00055.x
Adams, R., \& Ferreira, D. (2007). A theory of friendly boards. Journal of Finance, 62, 217-250. https://doi.org/10.1111/j.1540-6261.2007. 01206.x

Albuquerque, A. M., \& Zhu, J. L. (2018). Has Section 404 of the SarbanesOxley Act discouraged corporate risk-taking? New evidence from a natural experiment. Available at SSRN: https://doi.org/10.2139/ssrn. 3049232

Altman, E. I. (1968). Financial ratios, discriminant analysis and the prediction of corporate bankruptcy. Journal of Finance, 23, 589-609. https:// doi.org/10.1111/j.1540-6261.1968.tb00843.x

Amihud, Y., \& Lev, B. (1981). Risk reduction as a managerial motive for conglomerate mergers. Bell Journal of Economics, 12, 605-617. https://doi.org/10.2307/3003575

Andrade, S. C., Bernile, G., \& Hood, F. M. (2014). SOX, corporate transparency, and the cost of debt. Journal of Banking \& Finance, 38, 145-165. https://doi.org/10.1016/j.jbankfin.2013.10.001

Aretz, K., Banerjee, S., \& Pryshchepa, O. (2019). In the path of the storm: Does distress risk cause industrial firms to risk-shift? Review of Finance, 23(6), 1115-1154. https://doi.org/10.1093/rof/rfy028

Armstrong, C. S., \& Vashishtha, R. (2012). Executive stock options, differential risk-taking incentives, and firm value. Journal of Financial Economics, 104, 70-88. https://doi.org/10.1016/j.jfineco.2011.11.005

Arping, S., \& Sautner, Z. (2013). Did SOX Section 404 make firms less opaque? Evidence from cross-listed firms. Contemporary Accounting Research, 30, 1133-1165. https://doi.org/10.1111/j.1911-3846.2012.01188.x

Ashbaugh-Skaife, H., Collins, D. W., Kinney, W. R. J., \& Lafond, R. (2009). The effect of SOX internal control deficiencies on firm risk and cost of equity. Journal of Accounting Research, 47, 1-43. https://doi.org/10. 1111/j.1475-679X.2008.00315.x

Atanasov, V. A., \& Black, B. S. (2016). Shock-based causal inference in corporate finance research. Critical Finance Review, 5, 207-304. https:// doi.org/10.1561/104.00000036

Atanassov, J. (2013). Do hostile takeovers stifle innovation? Evidence from antitakeover legislation and corporate patenting. Journal of Finance, 68, 1097-1131. https://doi.org/10.1111/jofi.12019

Banerjee, S., Humphery-Jenner, M., \& Nanda, V. (2015). Restraining overconfident CEOs through improved governance: Evidence from the Sarbanes-Oxley Act. Review of Financial Studies, 28, 2812-2858. https://doi.org/10.1093/rfs/hhv034

Bargeron, L. L., Lehn, K. M., \& Zutter, C. J. (2010). Sarbanes-Oxley and corporate risk-taking. Journal of Accounting and Economics, 49(1-2), 3452. https://doi.org/10.1016/j.jacceco.2009.05.001

Bebchuk, L., Cohen, A., \& Ferrell, A. (2009). What matters in corporate governance? Review of Financial Studies, 22, 783-827. https://doi.org/ 10.1093/rfs/hhn099

Bebchuk, L. A., Cohen, A., \& Wang, C. C. (2013). Learning and the disappearing association between governance and returns. Journal of Financial Economics, 108, 323-348. https://doi.org/10.1016/j.jineco. 2012.10.004

Bhagat, S., \& Welch, I. (1995). Corporate research \& development investments international comparisons. Journal of Accounting and Economics, 19, 443-470. https://doi.org/10.1016/0165-4101(94)00391-H

Bradley, M., Jarrel, G., \& Kim, H. (1984). On the existence of an optimal capital structure: Theory and evidence. Journal of Finance, 39, 857-878. https://doi.org/10.1111/j.1540-6261.1984.tb03680.x

Brisley, N., Cai, J., \& Nguyen, T. (2021). Required CEO stock ownership: Consequences for risk-taking and compensation. Journal of Corporate Finance, 66, 101850. https://doi.org/10.1016/j.jcorpfin.2020.101850

Brown, A. (2011). Red-Blooded Risk: The Secret History of Wall Street. New Jersey: John Wiley \& Sons.

Bushee, B. J., \& Noe, C. F. (2000). Corporate disclosure practices, institutional investors, and stock return volatility. Journal of Accounting Research, 38, 171-202. https://doi.org/10.2307/2672914

Cain, M. D., McKeon, S. B., \& Solomon, S. D. (2017). Do takeover laws matter? Evidence from five decades of hostile takeovers. Journal of 
Financial Economics, 124, 464-485. https://doi.org/10.1016/j.jfineco. 2017.04.003

Campbell, J. Y., Hilscher, J., \& Szilagyi, J. (2008). In search of distress risk. Journal of Finance, 63, 2899-2939. https://doi.org/10.1111/j.15406261.2008.01416.x

Chang, X., \& Zhang, H. F. (2015). Managerial entrenchment and firm value: A dynamic perspective. Journal of Financial and Quantitative Analysis, 50, 1083-1103. https://doi.org/10.1017/S0022109015000423

Chhaochharia, V., \& Grinstein, Y. (2007). Corporate governance and firm value: The impact of the 2002 governance rules. Journal of Finance, 62 , 1789-1825. https://doi.org/10.1111/j.1540-6261.2007.01257.x

Clark, R. C. (2005). Corporate governance changes in the wake of the Sarbanes-Oxley Act: A morality tale for policymakers too. Georgia State University Law Review, 22, 251-312.

Cleary, S. (1999). The relationship between firm investment and financial status. Journal of Finance, 54, 673-692.

Cohen, D. A., Dey, A., \& Lys, T. Z. (2013). Corporate governance reform and executive incentives: Implications for investments and risk taking. Contemporary Accounting Research, 30, 1296-1332. https://doi.org/ 10.1111/j.1911-3846.2012.01189.x

Coles, J. L., Daniel, N. D., \& Naveen, L. (2006). Managerial incentives and risk-taking. Journal of Financial Economics, 79, 431-468. https://doi. org/10.1016/j.jfineco.2004.09.004

Core, J., \& Guay, W. (2002). Estimating the value of employee stock option portfolios and their sensitivities to price and volatility. Journal of Accounting Research, 40, 613-630.

Cornelli, F., Kominek, Z., \& Ljungqvist, A. (2013). Monitoring managers: Does it matter? Journal of Finance, 68, 431-481. https://doi.org/10. 1111/jofi.12004

Dey, A. (2010). The chilling effect of Sarbanes-Oxley: A discussion of Sarbanes-Oxley and corporate risk-taking. Journal of Accounting and Economics, 49, 53-57. https://doi.org/10.1016/j.jacceco.2009.06.003

Diamond, D. W. (1989). Reputation acquisition in debt markets. Journal of Political Economy, 97, 828-862. https://doi.org/10.1086/261630

Dikolli, S. S., Mayew, W. J., \& Nanda, D. (2014). CEO tenure and the performance-turnover relation. Review of Accounting Studies, 19, 281-327. https://doi.org/10.1007/s11142-013-9247-6

Dittmar, A., \& Mahrt-Smith, J. (2007). Corporate governance and the value of cash holdings. Journal of Financial Economics, 83, 599-634. https:// doi.org/10.1016/j.jfineco.2005.12.006

Duchin, R., Matsusaka, J. G., \& Ozbas, O. (2010). When are outside directors effective? Journal of Financial Economics, 96, 195-214. https:// doi.org/10.1016/j.jfineco.2009.12.004

Fama, E. F., \& French, K. R. (1993). Common risk factors in the returns on stocks and bonds. Journal of Financial Economics, 33, 3-56. https://doi. org/10.1016/0304-405X(93)90023-5

Fama, E. F., \& French, K. R. (1997). Industry costs of equity. Journal of Financial Economics, 43, 153-193. https://doi.org/10.1016/S0304405X(96)00896-3

Garvey, G., \& Milbourn, T. (2003). Incentive compensation when executives can hedge the market: Evidence of relative performance evaluation in the cross section. Journal of Finance, 58, 1557-1582. https:// doi.org/10.1111/1540-6261.00577

Garvey, G. T., \& Hanka, G. (1999). Capital structure and corporate control: The effect of antitakeover statutes on firm leverage. Journal of Finance, 54, 519-546. https://doi.org/10.1111/0022-1082.00116

Gillan, S. L., Hartzell, J. C., \& Starks, L. T. (2011). Tradeoffs in corporate governance: Evidence from board structures and charter provisions. Quarterly Journal of Finance, 01(04), 667-705. https://doi.org/10. $1142 /$ S2010139211000183

Giroud, X., \& Mueller, H. M. (2010). Does corporate governance matter in competitive industries? Journal of Financial Economics, 95, 312-331. https://doi.org/10.1016/j.jfineco.2009.10.008
Gompers, P., Ishii, J., \& Metrick, A. (2003). Corporate governance and equity prices. Quarterly Journal of Economics, 118, 107-156. https:// doi.org/10.1162/00335530360535162

Gormley, T. A., \& Matsa, D. A. (2016). Playing it safe? Managerial preferences, risk, and agency conflicts. Journal of Financial Economics, 122, 431-455. https://doi.org/10.1016/j.jfineco.2016.08.002

Guldiken, O., \& Darendeli, I. S. (2016). Too much of a good thing: Board monitoring and R\&D investments. Journal of Business Research, 69(8), 2931-2938. https://doi.org/10.1016/j.jbusres.2015.12.062

Guo, L., \& Masulis, R. W. (2015). Board structure and monitoring: New evidence from CEO turnovers. Review of Financial Studies, 28(10), 2770-2811. https://doi.org/10.1093/rfs/hhv038

Hall, B. J., \& Liebman, J. B. (1998). Are CEOS really paid like bureaucrats? The Quarterly Journal of Economics, 113(3), 653-691.

Harford, J., Mansi, S. A., \& Maxwell, W. F. (2008). Corporate governance and firm cash holdings in the US. Journal of Financial Economics, 87, 535-555. https://doi.org/10.1016/j.jfineco.2007.04.002

Harris, M., \& Raviv, A. (2008). A theory of board control and size. Review of Financial Studies, 21, 1797-1832. https://doi.org/10.1093/rfs/hhl030

Hayes, R. M., Lemmon, M., \& Qiu, M. (2012). Stock options and managerial incentives for risk taking: Evidence from FAS 123R. Journal of Financial Economics, 105, 174-190. https://doi.org/10.1016/j.jfineco.2012. 01.004

Hazarika, S., Karpoff, J. M., \& Nahata, R. (2012). Internal corporate governance, CEO turnover, and earnings management. Journal of Financial Economics, 104, 44-69. https://doi.org/10.1016/j.jfineco.2011.10.011

Hirshleifer, D., \& Thakor, A. V. (1992). Managerial conservatism, project choice, and debt. Review of Financial Studies, 5, 437-470. https://doi. org/10.1093/rfs/5.3.437

Holmström, B. (1999). Managerial incentive problems: A dynamic perspective. Review of Economic Studies, 66, 169-182. https://doi.org/10. 1111/1467-937X.00083

Holmström, B., \& Costa, J. R. I. (1986). Managerial incentives and capital management. Quarterly Journal of Economics, 101, 835-860. https:// doi.org/10.2307/1884180

Jensen, M. C. (1988). Takeovers: Their causes and consequences. Journal of Economic Perspectives, 2, 21-48.

Jensen, M. C., \& Meckling, W. H. (1976). Theory of the firm: Managerial behavior, agency costs and ownership structure. Journal of Financial Economics, 3, 305-360. https://doi.org/10.1016/0304-405X(76) 90026-X

Jensen, M. C., \& Ruback, R. S. (1983). The market for corporate control: The scientific evidence. Journal of Financial Economics, 11, 5-50. https://doi.org/10.1016/0304-405X(83)90004-1

Jin, L. (2002). CEO compensation, diversification, and incentives. Journal of Financial Economics, 66, 29-63. https://doi.org/10.1016/S0304-405X (02)00150-2

John, K., \& Kadyrzhanova, D. (2008). Peer effects in corporate governance. Available at SSRN: https://ssrn.com/abstract\&\#x0003D;1108860

John, K., Li, Y., \& Pang, J. (2016). Does corporate governance matter more for high financial slack firms? Management Science, 63, 1-21. https:// doi.org/10.1287/mnsc.2015.2392

John, K., Litov, L., \& Yeung, B. (2008). Corporate governance and risk-taking. Journal of Finance, 63, 1679-1728. https://doi.org/10.1111/j. 1540-6261.2008.01372.x

Kim, B. (2003). Recent developments. Harvard Journal on Legislation, 40, 235-252.

Kothari, S., Laguerre, T., \& Leone, A. (2002). Capitalization versus expensing: Evidence on the uncertainty of future earnings from capital expenditures versus R\&D outlays. Review of Accounting Studies, 7, 355-382. https://doi.org/10.1023/A:1020764227390

La Porta, R., Lopez-de Silanes, F., \& Shleifer, A. (1999). Corporate ownership around the world. Journal of Finance, 54, 471-517. 
Lambert, R. A. (1986). Executive effort and selection of risky projects. RAND Journal of Economics, 17, 77-88. https://doi.org/10.2307/ 2555629

Linck, J. S., Netter, J. M., \& Yang, T. (2008). The determinants of board structure. Journal of Financial Economics, 87, 308-328. https://doi.org/ 10.1016/j.jneco.2007.03.004

Linck, J. S., Netter, J. M., \& Yang, T. (2009). The effects and unintended consequences of the Sarbanes-Oxley Act on the supply and demand for directors. Review of Financial Studies, 22, 3287-3328. https://doi. org/10.1093/rfs/hhn084

Low, A. (2009). Managerial risk-taking behavior and equity-based compensation. Journal of Financial Economics, 92, 470-490. https://doi.org/ 10.1016/j.jfineco.2008.05.004

Malmendier, U., \& Tate, G. (2005). CEO overconfidence and corporate investment. Journal of Finance, 60, 2661-2700. https://doi.org/10. 1111/j.1540-6261.2005.00813

Merton, R. C. (1974). On the pricing of corporate debt: The risk structure of interest rates. Journal of Finance, 29, 449-470. https://doi.org/10. $2307 / 2978814$

Newman, H. A., \& Mozes, H. A. (1999). Does the composition of the compensation committee influence CEO compensation practices? Financial Management, 28(3), 41-53.

Pástor, V. L. S., \& Veronesi, P. (2009). Technological revolutions and stock prices. American Economic Review, 99, 1451-83. https://doi.org/10. 1257/aer.99.4.1451

Scholten, R. (2005). Investment decisions and managerial discipline: Evidence from the takeover market. Financial Management, 34, 35-61.

Sundaramurthy, C. (2000). Antitakeover provisions and shareholder value implications: A review and contingency framework. Journal of Management, 26, 1005-1030. https://doi.org/10.1177/01492063000 2600501

Xu, Y., \& Malkiel, B. G. (2003). Investigating the behavior of idiosyncratic volatility. Journal of Business, 76, 613-645. https://doi.org/10.1086/ 377033

\section{AUTHOR BIOGRAPHY}

Oksana Pryshchepa is an Assistant Professor at the Accounting and Finance Section at Cardiff Business School. She received her Ph.D. in Finance from Lancaster University Management School. Her current research examines the role of corporate governance mechanisms in mitigating agency conficts and in firm's investment and financing decisions, in particular the impact of governance reforms and executive compensation on risk-taking behavior and the effect of boards and board networks on issuance decisions.

\section{SUPPORTING INFORMATION}

Additional supporting information may be found online in the Supporting Information section at the end of this article.

How to cite this article: Pryshchepa O. Disciplining entrenched managers through corporate governance reform: Implications for risk-taking behavior. Corp Govern Int Rev. 2021;29:328-351. https://doi.org/10.1111/corg.12370 


\section{APPENDIX}

\section{TABLE A1 Variable Definitions}

\begin{tabular}{|c|c|}
\hline Variable & Definition \\
\hline \multicolumn{2}{|c|}{ Entrenchment Measures } \\
\hline E-index & $\begin{array}{l}\text { Entrenchment index constructed using six anti-takeover provisions from RiskMetrics and following Bebchuk, Cohen \& } \\
\text { Ferrel (2009). The E-index gives a score, from } 0 \text { to } 6 \text {, for each anti-takeover provision the company has in a given year. } \\
\text { More provisions indicate more insulation from or less exposure to the market for corporate controls and hence, a higher } \\
\text { degree of managerial power and control over the company. This set includes staggered boards, limits to shareholder by- } \\
\text { law amendments, supermajority requirements for mergers and for charter amendments, poison pills and golden } \\
\text { parachutes. }\end{array}$ \\
\hline G-index & $\begin{array}{l}\text { Governance index that includes } 24 \text { shareholder rights provisions from RiskMetrics and is constructed after Gompers,Ishii, \& } \\
\text { Metrick (2003). The index measures the balance of power between managers and shareholders. Higher values of the } \\
\text { index indicate weaker shareholder protection and hence higher power for management and poorer governance structure. } \\
\text { The } 24 \text { provisions include anti-greenmail, blank check preferred stock, business combination laws, bylaw and charter } \\
\text { amendment limitations, control-share cash-out laws, staggered boards, compensation plans with changes-in-control } \\
\text { provisions, director indemnification and director indemnification contracts, supermajority requirements for mergers and } \\
\text { for charter amendments, cumulative voting, directors' duties, fair price provisions, golden parachutes, limitations on } \\
\text { director liability, pension parachutes, poison pills, secret ballots, executive severance agreements, silver parachutes, } \\
\text { special meeting limitations, unequal voting rights, and limitations on action by written consent. }\end{array}$ \\
\hline Takeover Index & $\begin{array}{l}\text { A firm-level index of takeover protection developed by Cain, McKeon \& Solomon (2017). The index is a composite measure } \\
\text { of three determinants of hostile takeovers: (i) legal that comprise the variation in } 17 \text { takeover laws enacted during } \\
\text { 1965-2014, (ii) macroeconomic (aggregate capital liquidity), and (iii) firm-specific (firm age). Higher values of the index } \\
\text { indicate lower susceptibility to takeovers and hence, proxy for higher entrenchment and poorer corporate governance. } \\
\text { The data on the takeover index is taken from Stephen McKeon's website at https://pages.uoregon.edu/smckeon/. }\end{array}$ \\
\hline SB\&PP Index & $\begin{array}{l}\text { Entrenchment index that combines only two anti-takeover provisions (ATPs) from E-index, the staggered board and poison } \\
\text { pill provisions and ranges from } 0 \text { to } 2 \text { (John and Kadyrzhanova, 2008). The premise behind this proxy is that staggered } \\
\text { boards and poison pills represent the most severe impediment to hostile takeovers, and are therefore considered the } \\
\text { most effective ATPs. Higher values of the index indicate higher entrenchment. The index is constructed using RiskMetrics } \\
\text { data. }\end{array}$ \\
\hline
\end{tabular}

\section{SOX Measure}

\section{Risk-Taking Measures}

Total Risk

Imputed measure of risk. Standard deviation of weekly returns of a portfolio that mimicks firm's industry composition.

Systematic Risk

The square root of the explained variance in the regression of a firm's imputed weekly returns at the beginning of each year on the Fama \& French (1993) factors.

Idiosyncratic Risk

The square root of the unexplained variance in the regression of a firm's imputed weekly returns at the beginning of each year on the Fama and French (1993) factors.

Investment Measures

Capex

Net Investment

$R \& D$

Acquisition Expense

PP\&E Growth

Asset Growth
Capital expenditures (capx)-to-beginning of fiscal year PP\&E (ppegt).

Total investment net of asset sales (sppe)-to-beginning of fiscal year PP\&E (ppegt).

Research \& Development expenditures (xrd)-to-beginning of fiscal year PP\&E (ppegt).

Acquisition expense (aqc)-to-beginning of fiscal year PP\&E (ppegt).

Growth in PP\&E (ppegt) from beginning to the end of the year.

Growth in total assets (at) from beginning to the end of the year.

\section{Value and Operating Performance Measures}

Tobin's Q

Market-to-Book Equity
A firm's Tobin's Q computed as total assets (at) minus book value of equity (ceq) plus market value of equity (abs (prc) $\times$ shrout) minus deferred taxes (txdc) all scaled by total assets (at). The firm's industry-adjusted Tobin's $Q$ is defined as its Tobin's Q less the average Tobin's Q for all firms in its Fama \& French (1997) 30-industry classification in that year.

Market value of equity divided by book value of equity ( $(a b s(p r c) \times$ shrout/ceq). Book value of equity is adjusted following Campbell, Hilscher, \& Szilagyi (2008). The firm's industry-adjusted market-to-book value of equity is defined as its market-to-book ratio less the average market-to-book ratio for all firms in its Fama \& French (1997) 30-industry classification in that year.

ROA A firm's return on assets (ROA) defined as operating income after depreciation (ebit) divided by total assets (at). 
TABLE A1 (Continued)

\begin{tabular}{|c|c|}
\hline Variable & Definition \\
\hline Cash Flow & $\begin{array}{l}\text { The firm's cash flow computed as the sum of depreciation and amortization and income before extraordinary items (dp }+\mathrm{ib} \text { ) } \\
\text { divided by last year's total assets (at). }\end{array}$ \\
\hline Z-score & $\begin{array}{l}\text { Altman's (1968) Z-score defined as } 3.3 \times \text { operating income (ebit) }+ \text { sales (sales) }+1.4 \times \text { retained earnings }(\mathrm{re})+1.2 \times[\text { current } \\
\text { assets (act)- current liabilities (lct)] all scaled by assets (at). Z-score proxies for firm financial health, with higher values } \\
\text { indicating a better financial health and profitability. }\end{array}$ \\
\hline
\end{tabular}

\section{Other Firm Characteristics}

LN (Assets)

Natural logarithm of book value of total assets (at) deflated to 2010 dollars.

Leverage

Total debt divided by book value of assets ((dlc+dltt)/at).

Firm Age

Number of years the firm is listed in Compustat prior to fiscal year end.

Slack

Following Cleary (1999), financial slack is defined as cash and short-term investments (che) $+(0.5 \times$ inventory (invt)) + $(0.70 \times$ accounts receivable $(r e c t))-$ short-term loans (dlc) all scaled by net fixed assets (ppent).

Effective Cost of Debt

Total interest expense (xint) divided by the sum of debt in current liabilities (dlc) and long-term debt (dltt).

Dividends

Cash dividends (dv) divided by the previous year book value of assets (at).

Debt Issuance

Total debt issuance defined as the sum of long-term debt (dltis - dltr) and change in short-term debt (chgstd) divided by the previous year book value of assets (at).

Equity Issuance Total equity issuance defined as sale of common and preferred stock (sstk) net of purchase of common and preferred stock (prstkc).

\section{CEO Characteristics}

CEO Stock Ownership

CEO's stock ownership (shrown excl opts val $\times$ prc) as a fraction of firm market value of equity (shrout $\times$ abs (prc)).

CEO Option Ownership

CEO's option ownership as a fraction of firm market value of equity (shrout $\times$ abs (prc)). The value of stock options is computed as the sum of the value of past option grants (opt val unex grant+opt val ex grant) and of current option grants. The value of current option grants is estimated using Black-Scholes option pricing model following approach detailed in Core and Guay (2002) and Hayes, Lemmon, and Qiu (2012).
Delta
A CEO's total portfolio delta is defined as the dollar increase in wealth for a $1 \%$ increase in stock price and constructed following Hayes, Lemmon, \& Qiu (2012).
Vega
CEO's total portfolio vega is defined as an increase in option-wealth for a 0.01 standard deviation increase in stock volatility and constructed following Hayes, Lemmon, \& Qiu (2012).

In (CEO Tenure) The natural log of one plus the number of years that the CEO has been the CEO of the company.

In (CEO Age) The natural log of the CEO's age.

In (CEO Turnover) An indicator variable equal to one if the identity of the CEO changes in a given year, and zero otherwise.

CEO Overconfidence An option-based measure of CEO's overconfidence defined following Malmendier \& Tate (2005) and Banerjee et al. (2016) as the degree of the in-the-moneyness of the CEO's vested stock options. To construct it, I use the total value-per option of the in-the-money options from ExecuComp by dividing the value of all unexercised exercisable options (opt_unex_est_val) by the number of options (opt_unex_exer_num), and then I scale this 'value-per-option' by the price at the end of the fiscal year (abs (prc))

\section{Information Cost Variables}

Number of analysts

The number of analysts who posted forecasts about the firm in a given year from IBES database. Forecasts from the same analyst identifier and the same brokerage house are considered to be the same analyst.

Dispersion of analyst The standard deviation of earnings forecasts across analysts prior to a quarterly earnings announcement, scaled by the forecasts firm's book value of assets and averaged across four quarters in a year.

Analyst forecast error

The absolute difference between the mean analyst earnings forecast prior to a quarterly earnings announcement and the actual earnings, scaled by the firm's book value of assets and averaged across four quarters in a year.

Information cost index Following Duchin, Matsusaka, and Ozbas (2010), the information cost index combines the three information cost measures above by averaging a firm's percentile ranking in the sample according to each measure. The reverse ranking is used for the number of analysts. The index is scaled to range from zero (low information cost) to one (high information cost).

The table offers details about the variables used in the analyses. The first column shows their names, and the second explains their calculation. I also note the CRSP/COMPUSTAT or ExecuComp mnemonics of the data items used to calculate the variables. 